\title{
Production of the biocommodities butanol and acetone from methanol with fluorescent FAST-tagged proteins using metabolically engineered strains of Eubacterium limosum
}

\author{
Maximilian Flaiz ${ }^{*}$, Gideon Ludwig, Frank R. Bengelsdorf(D) and Peter Dürre
}

\begin{abstract}
Background: The interest in using methanol as a substrate to cultivate acetogens increased in recent years since it can be sustainably produced from syngas and has the additional benefit of reducing greenhouse gas emissions. Eubacterium limosum is one of the few acetogens that can utilize methanol, is genetically accessible and, therefore, a promising candidate for the recombinant production of biocommodities from this $\mathrm{C} 1$ carbon source. Although several genetic tools are already available for certain acetogens including $E$. limosum, the use of brightly fluorescent reporter proteins is still limited.
\end{abstract}

Results: In this study, we expanded the genetic toolbox of E. limosum by implementing the fluorescence-activating and absorption shifting tag (FAST) as a fluorescent reporter protein. Recombinant E. limosum strains that expressed the gene encoding FAST in an inducible and constitutive manner were constructed. Cultivation of these recombinant strains resulted in brightly fluorescent cells even under anaerobic conditions. Moreover, we produced the biocommodities butanol and acetone from methanol with recombinant $E$. limosum strains. Therefore, we used $E$. limosum cultures that produced FAST-tagged fusion proteins of the bifunctional acetaldehyde/alcohol dehydrogenase or the acetoacetate decarboxylase, respectively, and determined the fluorescence intensity and product concentrations during growth.

Conclusions: The addition of FAST as an oxygen-independent fluorescent reporter protein expands the genetic toolbox of E. limosum. Moreover, our results show that FAST-tagged fusion proteins can be constructed without negatively impacting the stability, functionality, and productivity of the resulting enzyme. Finally, butanol and acetone can be produced from methanol using recombinant $E$. limosum strains expressing genes encoding fluorescent FAST-tagged fusion proteins.

Keywords: Acetogens, Anaerobes, C1-substrates, Fluorescence-activating and absorption shifting tag, Fluorescence reporter system, Fusion protein

*Correspondence: maximilian.flaiz@uni-ulm.de Institute of Microbiology and Biotechnology, Ulm University, Albert-Einstein-Allee 11,89081 Ulm, Germany

\begin{abstract}
Background
Acetogens are promising biocatalysts for the sustainable production of biocommodities since their ability to use carbon dioxide $\left(\mathrm{CO}_{2}\right)$ - and carbon monoxide $(\mathrm{CO})$-containing industrial waste gases as feedstock contributes to the reduction of greenhouse gas emissions. Nevertheless, the fermentation of such synthesis gas (syngas)
\end{abstract}

c) The Author(s) 2021. This article is licensed under a Creative Commons Attribution 4.0 International License, which permits use, sharing, adaptation, distribution and reproduction in any medium or format, as long as you give appropriate credit to the original author(s) and the source, provide a link to the Creative Commons licence, and indicate if changes were made. The images or other third party material in this article are included in the article's Creative Commons licence, unless indicated otherwise in a credit line to the material. If material is not included in the article's Creative Commons licence and your intended use is not permitted by statutory regulation or exceeds the permitted use, you will need to obtain permission directly from the copyright holder. To view a copy of this licence, visit http://creativeco mmons.org/licenses/by/4.0/. The Creative Commons Public Domain Dedication waiver (http://creativecommons.org/publicdomain/ zero/1.0/) applies to the data made available in this article, unless otherwise stated in a credit line to the data. 
faces technical challenges as the mass transfer of gases into the liquid state of media is quite poor and consequently limits microbial productivity [1]. An alternative to the $\mathrm{C} 1$ gases as a substrate is the use of methanol, since it bears the advantage of easy transport, storage, and is completely soluble in water, and does, therefore, not suffer from mass transfer issues [2]. Methanol can be produced from $\mathrm{CO}-, \mathrm{CO}_{2^{-}}$, and $\mathrm{H}_{2}$-containing syngas [3] and is a cheap, sustainable, and relatively pure feedstock for a variety of bacteria [4-7]. Several acetogens can utilize methanol via the Wood-Ljungdahl pathway [8], which has been elucidated in detail for Acetobacterium woodii [9]. Since the production of chemicals with methanol-utilizing acetogens seems to be auspicious, it is also of great interest to expand their molecular toolbox. Molecular tools with different levels of possibilities for metabolic engineering are available for acetogens such as A. woodii, Clostridium ljungdahlii, C. autoethanogenum, and E. limosum. That includes, e.g., genomic editing tools [10-14] and the expression of recombinant pathways to produce biocommodities such as butanol $[15,16]$, acetone [17-19], isopropanol [20], 3-hydroxybutyrate [21], or poly(3-hydroxybutyrate) [22]. However, fluorescent reporter systems which are well-established and often used tools in molecular biology to study gene expression [23, 24], promoter activities [25, 26], or the dynamics in microbial populations and co-cultures [27-29] are still restricted for acetogens, basically due to the lack of proteins that show bright fluorescence under anaerobic conditions. Recently, the fluorescence-activating and absorption shifting tag (FAST) [30] was established in $C$. acetobutylicum [31] and C. ljungdahlii [32] and opened the door for application in other anaerobic bacteria, since its fluorescence is bright and independent of oxygen. FAST is a small-sized protein with a mass of $14 \mathrm{kDa}$ that only shows fluorescence when it forms a non-covalent reversible complex with a fluorogenic ligand, a so-called fluorogen [30, 33]. Those fluorogens are hydroxybenzylidene rhodanine derivatives that are non-fluorescent by themselves and only show fluorescence when bound to FAST [30]. Due to the small size, FAST is perfectly suited for genetic fusion to any protein of interest (POI) [30]. Such fusion proteins enable investigations of protein localization and intracellular dynamics [31, 34-36].

In this study, we aimed to expand the genetic toolbox of the Gram-positive, methanol-utilizing acetogen E. limosum [37], which is one of the few acetogens that is genetically accessible [13, 38], by establishing FAST as a fluorescent reporter system. We used FAST to construct FAST-tagged fusion proteins. As an initial approach, the bifunctional acetaldehyde/alcohol dehydrogenase (AdhE2) from C. acetobutylicum, which mediates the reaction from butyryl-CoA to butanol [39], was tagged with FAST and the respective gene expressed in recombinant E. limosum strains (Fig. 1). Since E. limosum produces butyryl-CoA naturally [40], the heterologous expression of the gene encoding the FAST-tagged AdhE2 fusion protein is sufficient to produce butanol. As a second approach, the acetoacetate decarboxylase (Adc) originating from C. acetobutylicum was FAST-tagged and the respective gene used to assemble an artificial acetone production operon (APO) also including the genes thlA and $c t f A / B$ (encoding thiolase and acetoacetyl-CoA: acetate/butyrate-CoA transferase) originating from $C$. acetobutylicum [41, 42]. Thus, acetone production can be achieved by expression of the APO using recombinant E. limosum strains (Fig. 1). Evidence for heterologous production of the FAST-tagged AdhE2 and Adc fusion proteins within $E$. limosum mutants was provided by the determination of the fluorescence intensity of the respective bacterial populations producing the FAST-tagged fusion proteins during growth. Moreover, a comparison of production patterns of the biocommodities butanol and acetone using the $\mathrm{C} 1$ carbon source methanol provides first insight regarding stability, functionality, and productivity of the AdhE2 and Adc FAST-tagged fusion proteins.

\section{Results}

\section{Growth of E. limosum using different carbon sources}

E. limosum NG-6894 was cultivated heterotrophically using glucose or methanol as well as autotrophically using $\mathrm{H}_{2}+\mathrm{CO}_{2}$ and syngas as carbon and energy source. Heterotrophically cultivated cells using glucose reached a maximal optical density $\left(\mathrm{OD}_{600}\right)$ of 2.83 with a growth rate of $0.23 \mathrm{~h}^{-1}$. Cell cultures grown on various methanol concentrations of 50, 100, and 200 $\mathrm{mM}$ showed maximal $\mathrm{OD}_{600}$ values of $1.4,2$, and 2.6, respectively, while having a similar growth rate of about $0.09 \mathrm{~h}^{-1}$ (Fig. 2a and Table 1). Autotrophically grown cells using $\mathrm{H}_{2}+\mathrm{CO}_{2}$ showed the lowest growth rate of $0.02 \mathrm{~h}^{-1}$ and a maximal $\mathrm{OD}_{600}$ value of 0.6. Cultivation using syngas resulted in a maximal $\mathrm{OD}_{600}$ of 2.9 and a growth rate of $0.06 \mathrm{~h}^{-1}$ (Fig. $2 \mathrm{~b}$ and Table 1). E. limosum NG-6894 produced acetate and butyrate under heterotrophic as well as under autotrophic growth conditions, while the ratio between these products varied depending on the substrates used. Acetate and butyrate production started at the end of the exponential growth phase and reached their maximum in the stationary growth phase after the substrate was consumed completely. Heterotrophically grown cells using glucose showed a product ratio of acetate:butyrate of $6: 1$, which shifted to $2: 1$ when cells were cultivated with methanol, independent of the used amount of methanol (Table 1). E. limosum NG-6894 cells cultivated autotrophically using $\mathrm{H}_{2}+\mathrm{CO}_{2}$ produced 


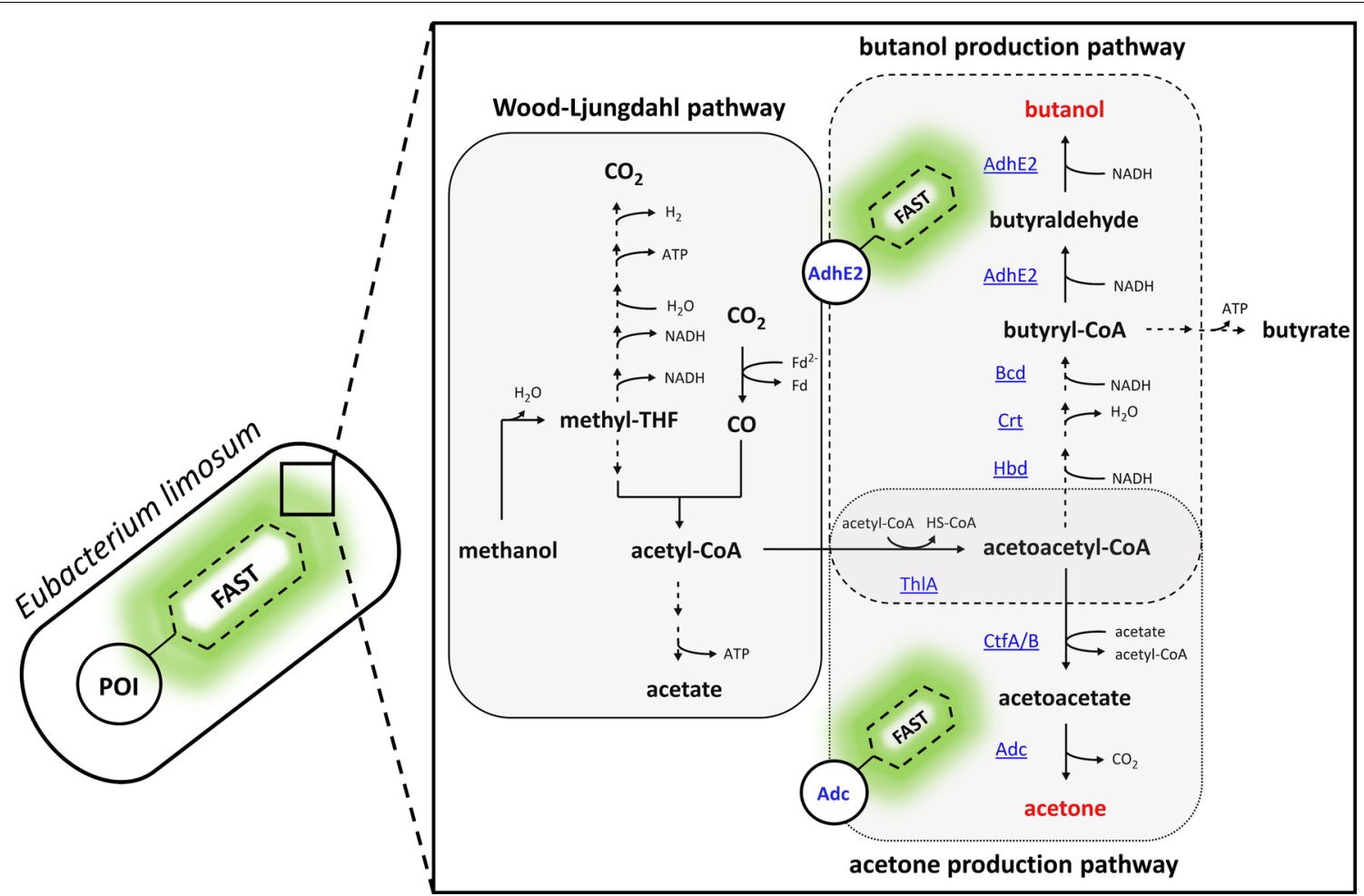

Fig. 1 Schematic overview of the WLP based on Kremp et al. [9] coupled with the recombinant butanol and acetone production pathway in $E$. limosum. Butanol and acetone production can be achieved with FAST-tagged AdhE2 and Adc fusion proteins, respectively. ThIA, thiolase; CtfA/B, acetoacetyl-CoA:acetate/butyrate-CoA transferase; Adc, acetoacetate decarboxylase; Hbd, 3-hydroxybutyryl-CoA dehydrogenase; Crt, crotonase; $\mathrm{Bcd}$, butyryl-CoA dehydrogenase; AdhE2, bifunctional acetaldehyde/alcohol dehydrogenase

the highest amounts of acetate $(85 \mathrm{mM})$ and only low amounts of butyrate $(2.4 \mathrm{mM})$, which resulted in a product ratio of 36:1. Cells grown using syngas achieved an acetate:butyrate ratio of 9:2 (Table 1). As a control, cells cultivated without the addition of a defined carbon source except for the standard medium components carbonate and yeast extract accomplished only one doubling and produced traces of acetate $(2.2-6 \mathrm{mM})$.

\section{Engineering of the fluorescence activation and absorption shifting tag in E. limosum}

After transformation, the recombinant E. limosum [pMTL83251_P ${ }_{\text {bgaL_FAST] }}$ expressed the FAST-encoding gene $(f e g)$ controlled by the lactose-inducible $b g a R-\mathrm{P}_{b g a L}$ promoter. Cells of that strain showed bright fluorescence during growth only in the presence of the fluorogen ${ }^{\mathrm{TF}}$ Lime after induction of gene expression (Fig. 3). E. limosum [pMTL83251_P $\mathrm{P}_{\text {bgaL_}}$ FAST] was cultivated on glucose and reached a 26 -fold higher maximum fluorescence intensity after $48 \mathrm{~h}$ of cultivation compared to the non-induced strain. Cells of the non-induced strain did not show any fluorescence except autofluorescence in the presence of ${ }^{\mathrm{TF}}$ Lime. Both, the induced and the non-induced strain reached similar maximal $\mathrm{OD}_{600}$ values of 3 and 3.1 after $24 \mathrm{~h}$ of cultivation, respectively. The empty vector control E. limosum [pMTL83251] reached an $\mathrm{OD}_{600}$ of 2.7 and showed only autofluorescence when supplemented with ${ }^{\mathrm{TF}}$ Lime (Fig. 3a). Fluorescence microscopy was used to image fluorescent cells (Fig. 3b). The resulting micrographs show brightly fluorescent cells of E. limosum [pMTL83251_P $\mathrm{P}_{\text {bgaL }}$ FAST] with induced gene expression. Non-induced as well as cells of the empty vector control $E$. limosum [pMTL83251] did not show any fluorescence. Nevertheless, fluorescence microscopy revealed an inhomogeneous population of fluorescent and non-fluorescent $E$. limosum [pMTL83251_P ${ }_{\text {ggaL_FAST] }}$ cells. E. limosum [pMTL83251_P $\mathrm{P}_{\text {bgaL_}}$ FAST] cells expressing $f e g$ and cultivated under equal growth conditions were analyzed at single cell level using flow cytometry (Fig. 3c). Initial autofluorescence of cells of the empty vector control strain E. limosum [pMTL83251] was determined and gated as non-fluorescent events. Cells of the strain E. limosum [pMTL83251_P ${ }_{\text {bgaL_}}$ FAST] with lactose-induced feg expression resulted in a clear shift showing a population with green fluorescence and confirming the results obtained by fluorescence microscopy. Flow cytometry data revealed that in the late exponential growth phase 

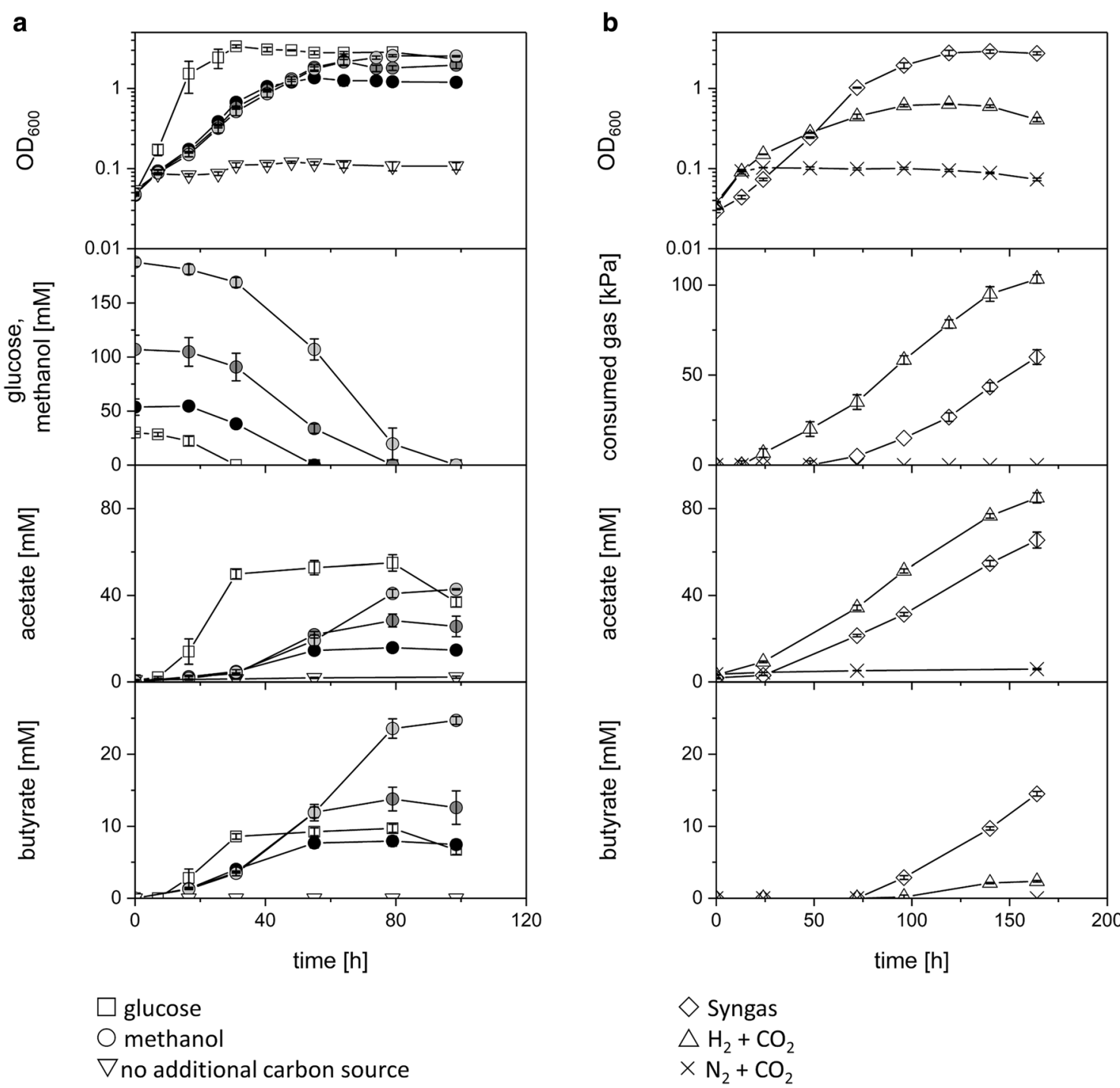

Fig. 2 a Heterotrophic and $\mathbf{b}$ autotrophic growth experiments using E. limosum NG-6894 cultivated on different carbon and energy sources. $E$. limosum was cultivated with 30 mM glucose (white); 50 (black), 100 (dark gray), or 200 mM (gray) methanol; without additional carbon source; Syngas; $\mathrm{H}_{2}+\mathrm{CO}_{2} ; \mathrm{N}_{2}+\mathrm{CO}_{2}$. $\mathrm{OD}_{600}$, glucose, methanol, and gas consumption (absolute value of accumulated pressure loss) as well as acetate and butyrate production were monitored. Error bars indicate standard deviations. $\mathrm{n}=3$

$62 \%$ of induced E. limosum [pMTL83251_P ${ }_{b g a L}$ FAST] cells were fluorescent, while $38 \%$ of them were non-fluorescent. The number of fluorescent cells increased in the stationary growth phase up to $72 \%$. In the late stationary growth phase, after $72 \mathrm{~h}$ of cultivation, the number of fluorescent cells decreased to $59 \%$. The population of the non-induced cells showed no shift and were non-fluorescent during all determined time points (Fig. 3d).

Furthermore, the fluorescence of FAST-producing cells cultivated with methanol as carbon and energy source was examined. In addition to E. limosum [pMTL83251_P $\mathrm{P}_{\text {ggaL_}}$ FAST] a strain termed $E$.

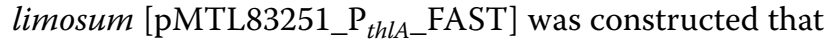
expressed $f e g$ under the control of the constitutive $\mathrm{P}_{\text {thlA }}$ promoter. E. limosum [pMTL83251] harboring the empty vector control showed only autofluorescence when the fluorogen ${ }^{\mathrm{TF}}$ Lime was supplemented (Fig. 4a). The constitutive expression of feg by E. limosum [pMTL83251_ $\mathrm{P}_{\text {thlA_}}$ FAST] caused a clear and increasing fluorescence during growth and a maximum intensity during the stationary stage (Fig. 4b). The fluorescence intensity of cells that produced FAST constitutively was 5.1 -fold higher compared to the autofluorescence of $E$. limosum [pMTL83251]. The lactose-induced expression of feg by 
Table 1 Comparison of growth characteristics and products of E. limosum NG-6894 cultivated using various carbon and energy sources

\begin{tabular}{|c|c|c|c|c|c|c|c|c|}
\hline \multirow[t]{2}{*}{ Substrate } & \multirow[t]{2}{*}{ Max. $O D_{600}$} & \multirow[t]{2}{*}{$\begin{array}{l}\text { Growth rate } \\
\left(\mathrm{h}^{-1}\right)\end{array}$} & \multirow[t]{2}{*}{$\begin{array}{l}\text { Doubling } \\
\text { time (h) }\end{array}$} & \multicolumn{2}{|c|}{ Products (mM) } & \multicolumn{2}{|c|}{$\begin{array}{l}\text { Products ( } \mathrm{mol} / 100 \mathrm{~mol} \\
\text { substrate) }\end{array}$} & \multirow[t]{2}{*}{$\begin{array}{l}\text { Product ratio } \\
\text { (acetate:butyrate) }^{\mathrm{a}}\end{array}$} \\
\hline & & & & Acetate & Butyrate & Acetate & Butyrate & \\
\hline \multicolumn{9}{|l|}{ Glucose } \\
\hline $30 \mathrm{mM}$ & 2.8 & 0.23 & 3 & 55 & 9.7 & 183.2 & 32.4 & $6: 1$ \\
\hline \multicolumn{9}{|l|}{ Methanol } \\
\hline 50 mM & 1.4 & 0.09 & 7.7 & 15.8 & 8 & 29.5 & 14.8 & $2: 1$ \\
\hline $100 \mathrm{mM}$ & 2 & 0.09 & 7.7 & 28.4 & 13.8 & 26.6 & 12.9 & $2: 1$ \\
\hline $200 \mathrm{mM}$ & 2.6 & 0.09 & 7.7 & 42.8 & 24.7 & 22.8 & 13.1 & $2: 1$ \\
\hline \multicolumn{9}{|l|}{ Gases } \\
\hline $\mathrm{H}_{2}+\mathrm{CO}_{2}$ & 0.6 & 0.02 & 34.7 & 85 & 2.4 & n.d. & n.d. & $36: 1$ \\
\hline Syngas & 2.9 & 0.06 & 11.6 & 65.5 & 14.5 & n.d. & n.d. & $9: 2$ \\
\hline
\end{tabular}

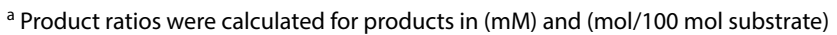
n.d. not determined

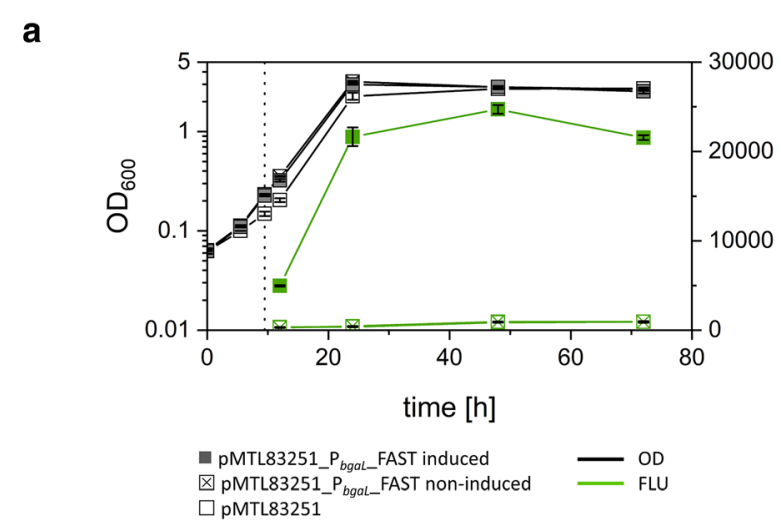

C

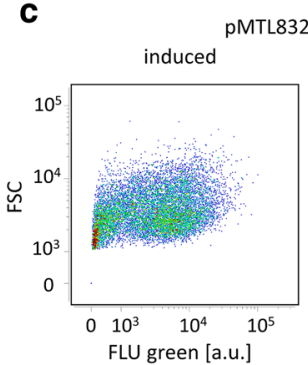

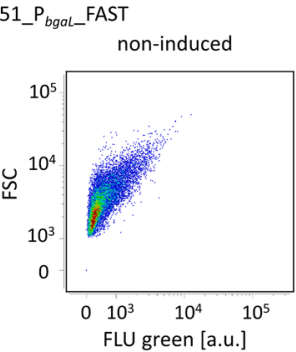
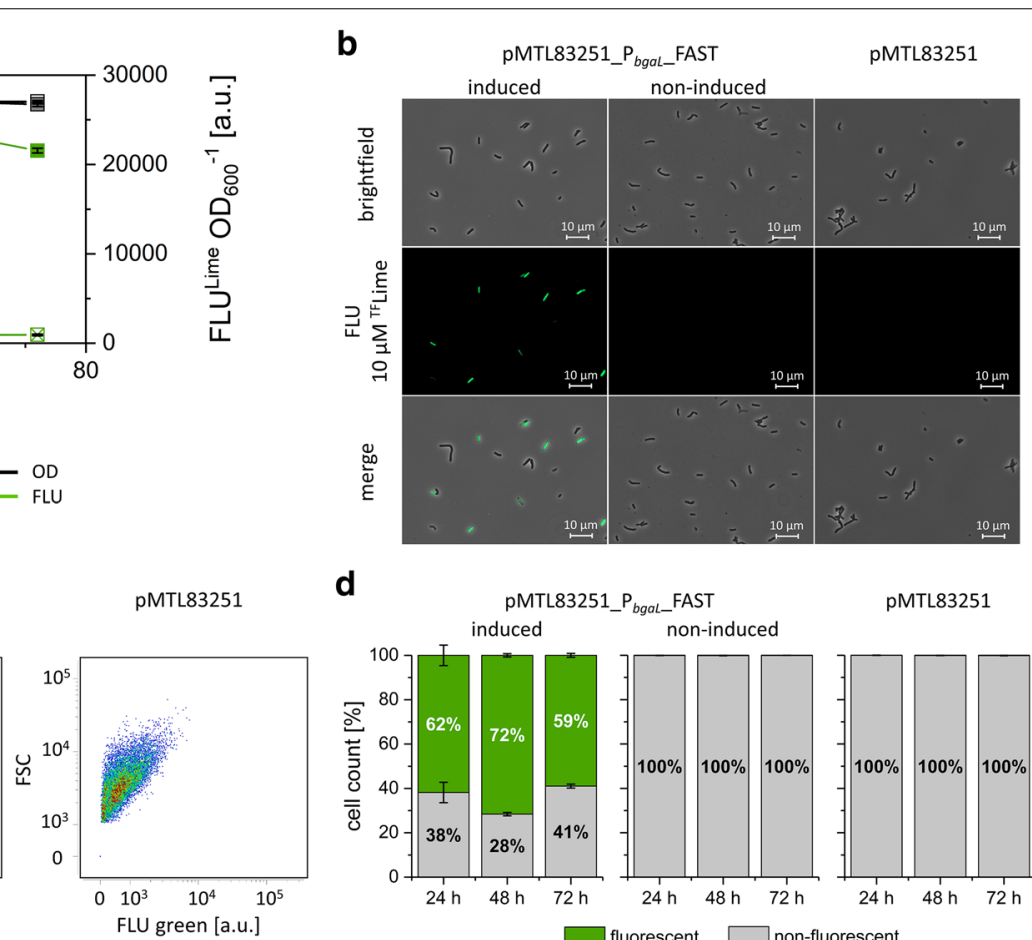

d

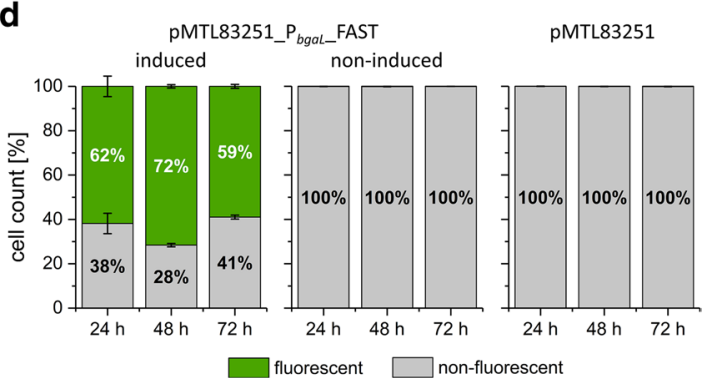

Fig. 3 a Fluorescence intensity of recombinant E. limosum strains during growth in presence of the fluorogen ${ }^{T}$ Lime. Cells were cultivated using

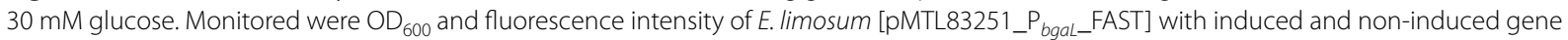
expression as well as E. limosum [pMTL83251]. b Micrographs of E. limosum [pMTL83251_P bgaL_FAST] and E. limosum [pMTL83251] after $72 \mathrm{~h}$ of incubation. Gene expression of cells was either induced or non-induced. c Density plots of E. limosum [pMTL83251_P bgaL_FAST] and E. limosum [pMTL83251] after $72 \mathrm{~h}$ of incubation. Gene expression of cells was either induced or non-induced. $\mathbf{d}$ Number of fluorescent $E$. limosum cells determined after $24 h, 48 h$, and $72 h$ cultivation. $n=3$

E. limosum [pMTL83251_P $\mathrm{P}_{\text {bgaL_}}$ FAST] caused clear fluorescence during cultivation and reached a maximum at $114 \mathrm{~h}$ in the stationary growth phase (Fig. 4c). Noninduced cells only showed autofluorescence in the same order of magnitude as cells of the empty vector control E. limosum [pMTL83251]. The fluorescence intensity of lactose-induced cells was 3.5- and 3.3-fold higher compared to non-induced cells and those of the empty 


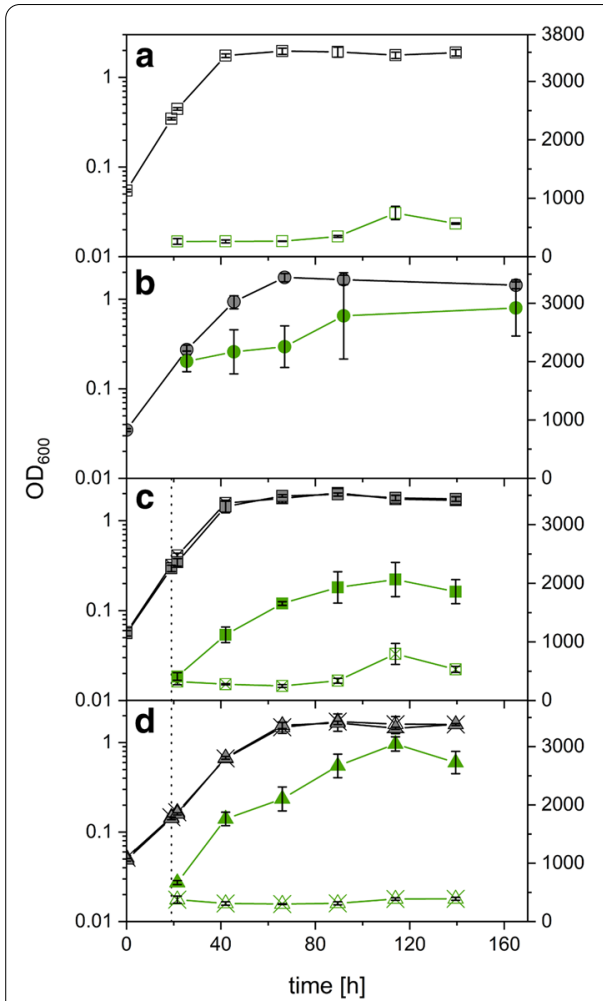

$\square$ pMTL83251

PMTL83251_P thIA_FAST $_{\text {PI }}$

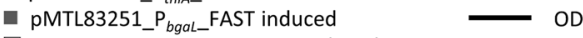

囚 pMTL83251_P

$\triangle$ pMTL83251_ $P_{\text {bgal_tdFAST2 }}$ induced

$\triangle$ PMTL83251_P $\mathrm{P}_{\text {bgal_ }}$ tdFAST2 non-induced

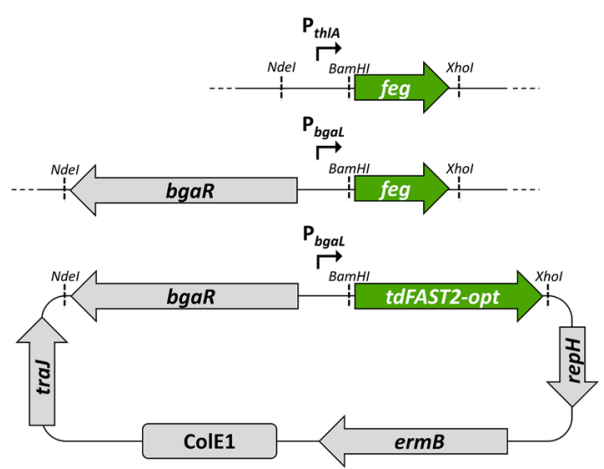

f
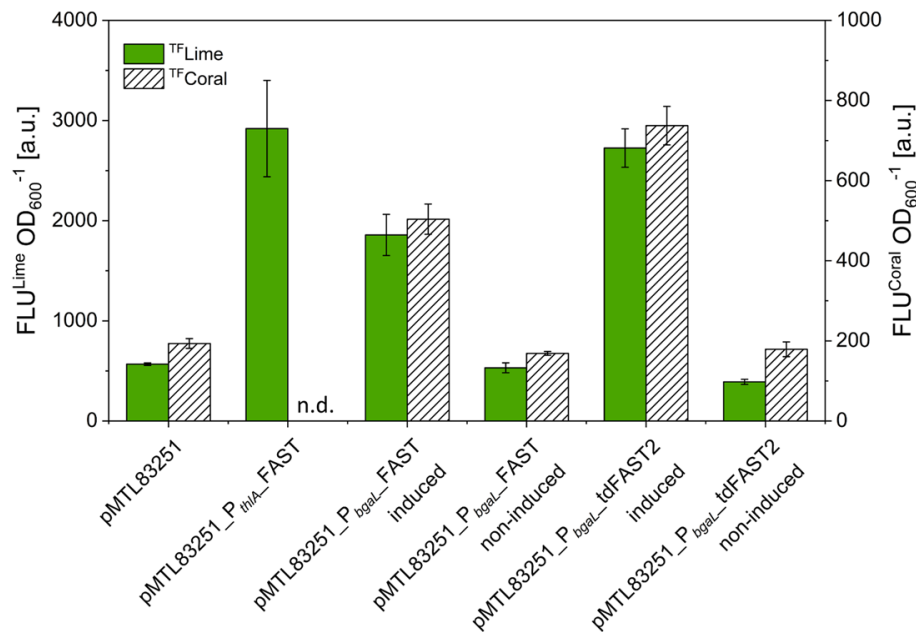

Fig. 4 Fluorescence intensity of recombinant $E$. limosum strains grown on methanol $(100 \mathrm{mM})$ in presence of the fluorogen ${ }^{\mathrm{TF}} \mathrm{Lime}$. a $\mathrm{OD}_{600}$ and fluorescence intensity of E. limosum [pMTL83251], b E. limosum [pMTL83251_P thlA_FAST], c E. limosum [pMTL83251_P bgal_FAST], and d d E. limosum

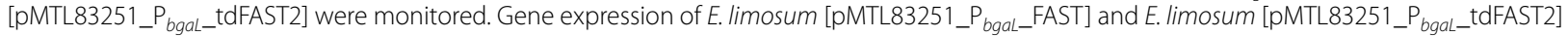
was either induced by lactose or non-induced. Time of induction with lactose is indicated with the vertical dotted line. $n=3$, error bars show standard deviation. e Genetic maps of plasmids representing pMTL83251_P

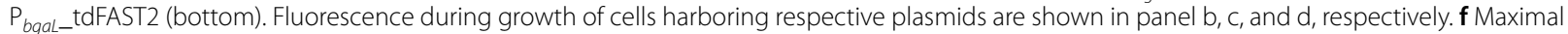
fluorescence intensity of recombinant $E$. limosum strains in the presence of the fluorogen ${ }^{\mathrm{TF}} \mathrm{Lime}$ or ${ }^{\mathrm{TF}} \mathrm{C}$.ral. Mean fluorescence was determined during stationary growth phase at an $\mathrm{OD}_{600}$ of $\sim 1.5, \mathrm{n}=3$, error bars show standard deviation. $\mathrm{n}=3$

vector control respectively. E. limosum [pMTL83251_ $\mathrm{P}_{\text {thlA_}}$ FAST] producing FAST constitutively showed a 1.6-fold higher fluorescence intensity comparing to that of cells with induced $f e g$ gene expression (Fig. 4f). Although cultivation of E. limosum [pMTL83251_P ${ }_{\text {bgaL- }}$ FAST] resulted in fluorescence, cells cultivated using glucose led to a 13.3-fold enhanced fluorescence intensity compared to cells cultivated on methanol.

Also, tdFAST2 was codon optimized for E. limosum and the respective gene used to construct the plasmid pMTL83251_ $\mathrm{P}_{\text {bgaL_ }}$ tdFAST2 harboring the gene tdFAST2-opt under the control of the bgaR- $\mathrm{P}_{\text {bgal }}$ lactose-inducible promoter (Fig. 4e). The induced expression of the codon-optimized tdFAST2-opt gene with E.

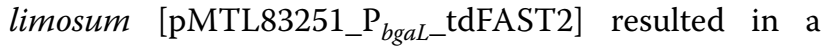

1.5-fold improved fluorescence compared to E. limosum [pMTL83251_P ${ }_{\text {bgaL_}}$ FAST] expressing feg controlled by the same promoter (Fig. 4f). The non-induced cells of E. limosum [pMTL83251_ $\mathrm{P}_{\text {bgaL }}$ tdFAST2] only showed autofluorescence.

Moreover, the fluorescence intensity of recombinant E. limosum strains expressing feg or tdFAST2-opt was examined when supplemented with the red fluorescent dye ${ }^{\mathrm{TF}}$ Coral after excitation at $516 \mathrm{~nm}$ (Fig. 4f). The use of the fluorogen ${ }^{\mathrm{TF}}$ Coral caused clear fluorescence of $E$. limosum [pMTL83251_P gene expression and showed 3- and 2.6-fold higher intensities compared to non-induced cells and those harboring the empty vector control, respectively. Furthermore, induced E. limosum [pMTL83251_P $\mathrm{P}_{\text {bgaL }}$ tdFAST2] cells 
showed a 1.5-fold higher fluorescent intensity compared to induced cells of $E$. limosum [pMTL83251_P $\mathrm{P}_{\text {bgaL_}}$ FAST] in presence of ${ }^{\mathrm{TF}}$ Coral. Non-induced as well as cells of the empty vector control showed autofluorescence only.

\section{Butanol production using FAST-tagged AdhE2 fusion proteins by recombinant $E$. limosum strains}

FAST was fused to the $\mathrm{C}$ - or the $\mathrm{N}$-terminus of AdhE2 (CA_P0035) using a flexible glycine linker. The resulting fusion proteins were used to examine the impact of the fluorescent FAST tag on functionality and productivity of AdhE2. Both AdhE2 fusion proteins were heterologously produced using the strains E. limosum [pMTL83251_ $\mathrm{P}_{\text {bgaL_C-FAST-AdhE2] (C-terminal tag) and E. limo- }}$ sum [pMTL83251_P $\mathrm{P}_{\text {bgaL_N-FAST-AdhE2] (N-terminal }}$ tag). E. limosum [pMTL83251_P bgaL_AdhE2] produced the native AdhE2 from $C$. acetobutylicum and was constructed and served as a control for butanol production using glucose or methanol as a carbon source.
Cultivation of E. limosum [pMTL83251_P ${ }_{b g a L}$ C-FASTAdhE2] using glucose as a carbon source and induced gene expression resulted in a maximal $\mathrm{OD}_{600}$ of 2.5 and a growth rate of $0.16 \mathrm{~h}^{-1}$. Non-induced cells reached an $\mathrm{OD}_{600}$ of 3 with a growth rate of $0.17 \mathrm{~h}^{-1}$. Clear fluorescence was observed after induction of gene expression, proving production of the C-terminal FAST-tagged AdhE2 fusion protein. Fluorescence increased during growth and reached a maximum in the late exponential growth phase. Non-induced cells showed only autofluorescence. The acetate:butyrate ratio was $10: 1$ and $8: 1$ for induced and non-induced cells, respectively. Butanol and ethanol were produced after induction of gene expression of the gene encoding the C-terminal FAST-tagged AdhE2 fusion protein. Induced cells produced up to $1 \mathrm{mM}$ ethanol and $0.6 \mathrm{mM}$ butanol at the end of the exponential growth phase. Non-induced cells produced traces of ethanol $(0.3 \mathrm{mM}$ ), while no butanol was detected (Fig. 5a, Table 2, and Additional file 1: Table S1).

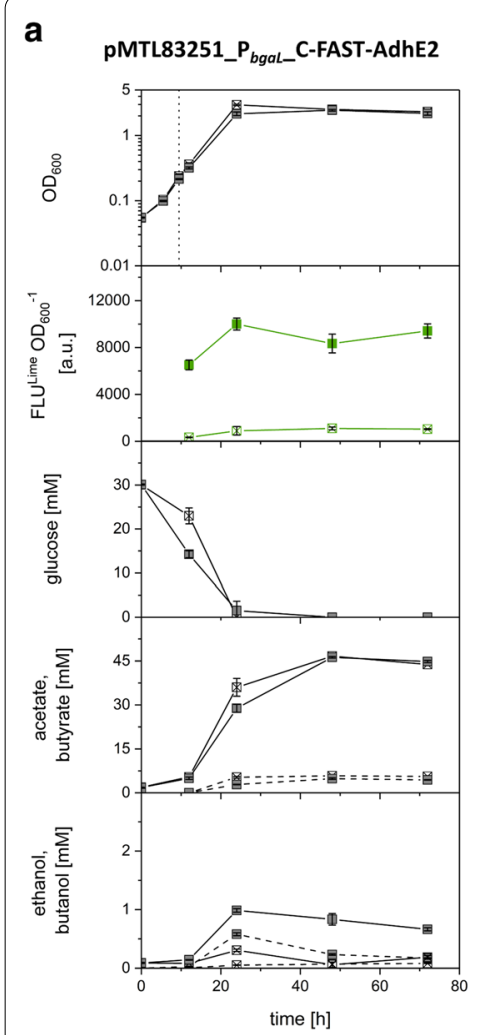

PMTL83251_P ${ }_{\text {bgal_N-FAST-AdhE2 }}$

b
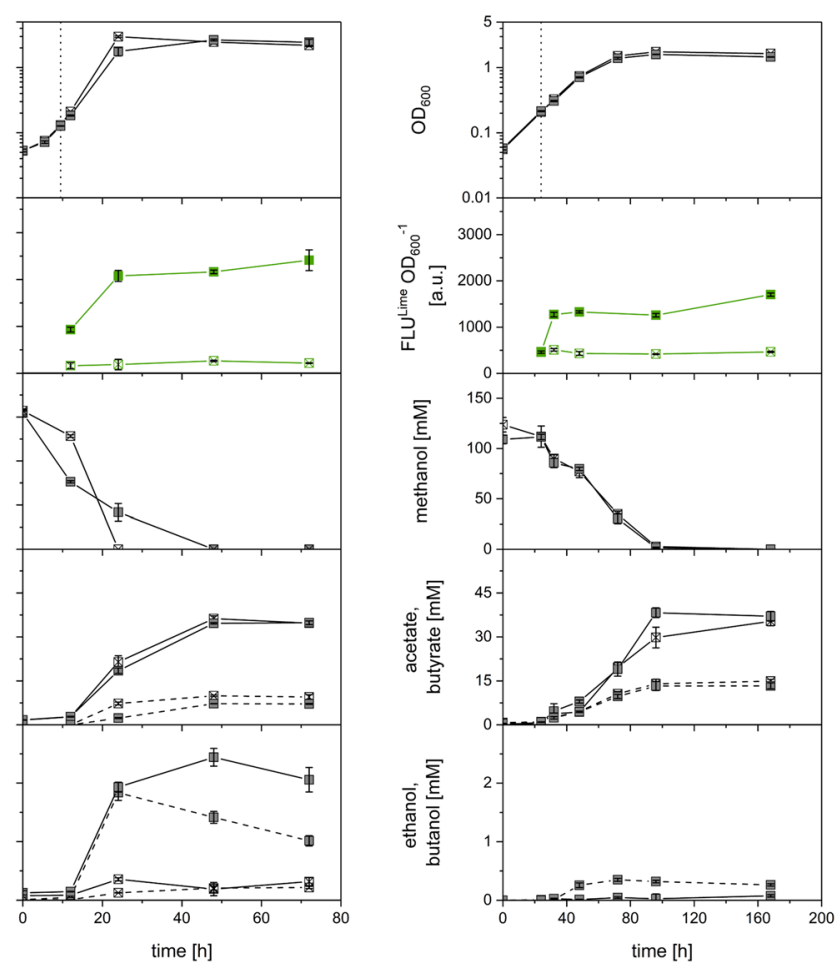

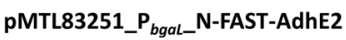
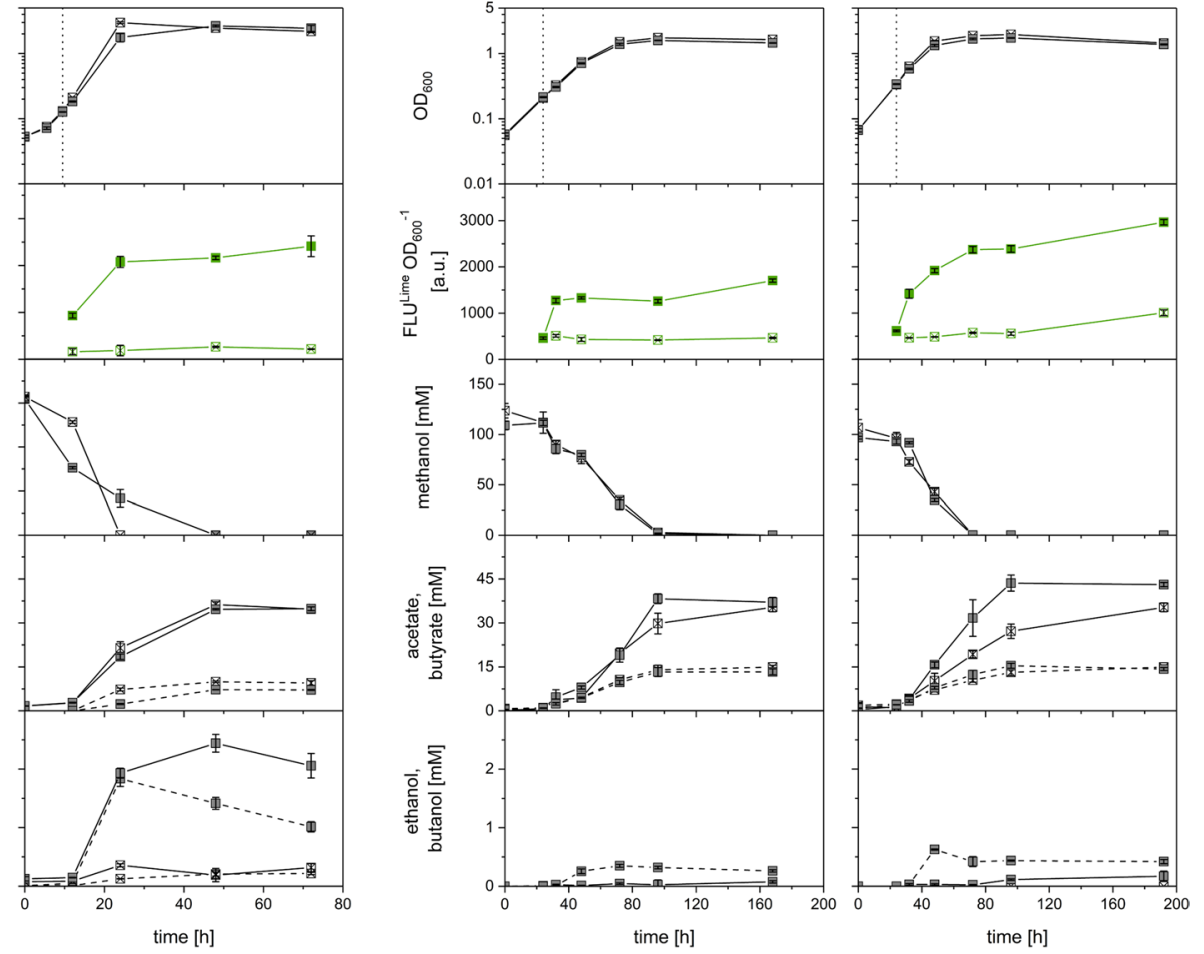

- induced cells

\non-induced cells

OD, glucose, methanol, acetate, ethanol
butyrate, butanol

Fig. 5 Growth experiment with E. limosum [pMTL83251_P bgaL_C-FAST-AdhE2] and E. limosum [pMTL83251_P bgaL_N-FAST-AdhE2]. Cells were cultivated using a $30 \mathrm{mM}$ glucose or $\mathbf{b} 100 \mathrm{mM}$ methanol. Gene expression of cells was either induced by lactose or non-induced. Time of induction with lactose is indicated with the vertical dotted line. $\mathrm{OD}_{600}$, fluorescence intensity in presence of ${ }^{\mathrm{TF}}$ Lime, glucose or methanol consumption as well as acetate, butyrate, ethanol, and butanol production were monitored. Error bars indicate standard deviations. $\mathrm{n}=3$ 
Table 2 Growth characteristics, ethanol, and butanol production of recombinant $E$. limosum strains characterized in growth experiments using glucose as carbon source

\begin{tabular}{|c|c|c|c|c|}
\hline $\begin{array}{l}\text { Recombinant } E \text {. } \\
\text { limosum strains }\end{array}$ & $O D_{\max }$ & $\begin{array}{l}\text { Growth } \\
\text { rate }\left(h^{-1}\right)\end{array}$ & Ethanol (mM) & Butanol (mM) \\
\hline \multicolumn{5}{|c|}{ pMTL83251_P bgal_AdhE2 } \\
\hline Induced & 2.5 & 0.17 & 1.9 & 1.6 \\
\hline Non-induced & 2.8 & 0.2 & 0.3 & 0.3 \\
\hline \multicolumn{5}{|c|}{ pMTL83251_P bgal_C-FAST-AdhE2 } \\
\hline Induced & 2.5 & 0.16 & 1 & 0.6 \\
\hline Non-induced & 3 & 0.17 & 0.3 & 0 \\
\hline \multicolumn{5}{|c|}{ pMTL83251_P bgal_N-FAST-AdhE2 } \\
\hline Induced & 2.7 & 0.18 & 2.4 & 1.8 \\
\hline Non-induced & 3 & 0.22 & 0.4 & 0.2 \\
\hline
\end{tabular}

Table 3 Growth characteristics, ethanol, and butanol production of recombinant $E$. limosum strains characterized in growth experiments using methanol as carbon source

\begin{tabular}{|c|c|c|c|c|}
\hline $\begin{array}{l}\text { Recombinant } E \text {. } \\
\text { limosum strains }\end{array}$ & $O D_{\max }$ & $\begin{array}{l}\text { Growth } \\
\text { rate }\left(\mathrm{h}^{-1}\right)\end{array}$ & Ethanol (mM) & Butanol (mM) \\
\hline \multicolumn{5}{|c|}{ pMTL83251_Pbgal_AdhE2 } \\
\hline Induced & 1.5 & 0.05 & 0.1 & 0.6 \\
\hline Non-induced & 1.7 & 0.05 & 0 & 0 \\
\hline \multicolumn{5}{|c|}{ pMTL83251_P bgal_C-FAST-AdhE2 } \\
\hline Induced & 1.6 & 0.05 & 0.1 & 0.4 \\
\hline Non-induced & 1.8 & 0.05 & 0 & 0 \\
\hline \multicolumn{5}{|c|}{ pMTL83251_P bgal_N-FAST-AdhE2 } \\
\hline Induced & 1.7 & 0.06 & 0.2 & 0.6 \\
\hline Non-induced & 2 & 0.06 & 0 & 0 \\
\hline
\end{tabular}

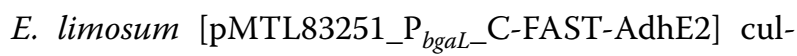
tivated using methanol as a carbon source showed a growth rate of $0.05 \mathrm{~h}^{-1}$ with induced and non-induced gene expression and reached $\mathrm{OD}_{600}$ values of 1.6 and 1.8, respectively. Clear fluorescence was determined after induction of gene expression that caused production of the FAST-tagged AdhE2 fusion protein and resulted in a 3.7-fold higher intensity compared to autofluorescence of non-induced cells. The induced culture showed an acetate:butyrate ratio of $3: 1$, while the non-induced culture showed a ratio of 2:1. Only the induced culture of $E$. limosum [pMTL83251_P ${ }_{\text {bgaL_C-CAST-AdhE2] produced }}$ traces of ethanol $(0.1 \mathrm{mM})$ and up to $0.4 \mathrm{mM}$ butanol from methanol at the end of the exponential growth phase. Non-induced strains did not produce any alcohols (Fig. 5c, Table 3, and Additional file 1: Table S2).

E. limosum [pMTL83251_P ${ }_{\text {ggaL_N-NAST-AdhE2] cells }}$ producing the $\mathrm{N}$-terminal FAST-tagged AdhE2 fusion protein, showed distinct fluorescence after induction of gene expression when cultivated with glucose, and reached a maximal $\mathrm{OD}_{600}$ of 2.7 with a growth rate of $0.18 \mathrm{~h}^{-1}$. Non-induced cells showed autofluorescence only and reached a maximal $\mathrm{OD}_{600}$ of 3 with a growth rate of $0.22 \mathrm{~h}^{-1}$. Fluorescence intensities were comparable to those determined for E. limosum [pMTL83251 $\mathrm{P}_{\text {bgaL_C-FAST-AdhE2] cultivated using glucose. An }}$ acetate:butyrate ratio of 5:1 was determined for induced and $4: 1$ for non-induced cells. Up to $2.4 \mathrm{mM}$ ethanol and $1.8 \mathrm{mM}$ butanol were produced at the end of the exponential growth phase with cells that expressed the gene encoding the N-terminal FAST-tagged AdhE2 fusion protein. Moreover, the uninduced cells produced up to $0.4 \mathrm{mM}$ ethanol and $0.2 \mathrm{mM}$ butanol (Fig. 5b, Table 2, and Additional file 1: Table S1).

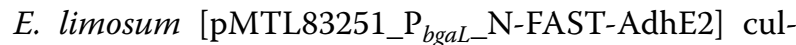
tivated using methanol showed a growth rate of 0.06 $\mathrm{h}^{-1}$, while the induced and non-induced cells reached an $\mathrm{OD}_{600}$ of 1.7 and 2, respectively. Induced cells produced the N-terminal FAST-tagged AdhE2 fusion protein after induction of gene expression and showed distinct fluorescence during growth with a maximum at the early stationary stage. Non-induced cells only showed autofluorescence. The acetate:butyrate ratio shifted from 3:1 to 2:1 for the induced and non-induced cells, respectively. Consequently, that strain produced $0.2 \mathrm{mM}$ of ethanol and $0.6 \mathrm{mM}$ of butanol at the end of the exponential growth phase. Non-induced cells again did not produce any alcohols (Fig. 5d, Table 3, and Additional file 1: Table S2). Finally, the strain that produced the N-terminal tagged version of AdhE2 showed a 1.4-fold higher fluorescence intensity compared to the strain that produced the C-terminal tagged version.

The control culture E. limosum [pMTL83251_ $\mathrm{P}_{\text {bgaL }}$ AdhE2] that produced the non-tagged version of AdhE2 showed similar characteristics regarding growth rate and production patterns. Cells were grown with glucose as a carbon source and reached a maximal $\mathrm{OD}_{600}$ of 2.5 with a growth rate of $0.17 \mathrm{~h}^{-1}$ when adhE2 gene expression was induced. Non-induced cells showed improved growth with a maximal $\mathrm{OD}_{600}$ of 2.8 and a growth rate of $0.2 \mathrm{~h}^{-1}$. The acetate:butyrate ratio was $6: 1$ in the case of the induced and 5:1 in the case of the non-induced cells. Gene expression of adhE2 in an inducible manner resulted in the production of up to $1.9 \mathrm{mM}$ ethanol and $1.6 \mathrm{mM}$ butanol at the end of the exponential growth phase. Non-induced cells only produced traces of ethanol and butanol $(0.3 \mathrm{mM})$ (Additional file 1: Fig. S1A, Table S1, Table 2). Both, the induced as well as the noninduced cells of E. limosum [pMTL83251_P $\mathrm{P}_{\text {bgaL_AdhE2] }}$ were cultivated with methanol and showed a growth rate of $0.05 \mathrm{~h}^{-1}$ with maximal $\mathrm{OD}_{600}$ values of 1.5 and 1.7, respectively. The acetate:butyrate ratio shifted to $3: 1$ for the induced and 2:1 for the non-induced cells. Induced 
expression of adhE2 caused production of $0.6 \mathrm{mM}$ butanol and traces of ethanol $(0.1 \mathrm{mM})$ in the late exponential growth phase during these batch experiments. The non-induced cells produced no alcohols from methanol (Additional file 1: Fig. S1B, Table S2, Table 3).

\section{Acetone production with FAST-tagged Adc fusion proteins using recombinant $E$. limosum strains}

The fluorescent FAST tag had no obvious negative effect on the catalytic properties of AdhE2. Subsequently, feg was fused to $a d c$ and the respective gene was expressed constitutively, together with the remaining genes of the APO, using the promoter $\mathrm{P}_{t h l A}$. Thus, the two strains designated E. limosum [pMTL83251_P thlA_C-FAST-Adc] and E. limosum [pMTL83251_P thlA_N-FAST-Adc] were constructed that produced either the $\mathrm{C}$ - or $\mathrm{N}$-terminal FAST-tagged Adc fusion protein, respectively. Those constructed strains were used to perform growth experiments to prove the functionality and productivity of the FAST-tagged Adc fusion proteins.

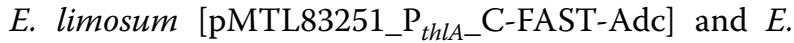
limosum [pMTL83251_P ${ }_{\text {thlA_}}$ N-FAST-Adc] were cultivated with glucose and showed growth rates of about 0.15 $\mathrm{h}^{-1}$ while reaching maximal $\mathrm{OD}_{600}$ values of 3.3 and 3.1, respectively (Fig. 6a and Table 4). Both strains produced acetone, acetate, and butyrate as metabolic end products (Additional file 1: Table S1 and Table 4). E. limosum [pMTL83251_P thla_C-FAST-Adc] cells that constitutively expressed the APO genes produced $0.8 \mathrm{mM}$ of acetone, while fluorescence intensity was 2.3 -fold higher compared to the autofluorescence of the empty vector control strain. E. limosum [pMTL83251_P ${ }_{\text {thlA_N-FAST-Adc] }}$ cells that expressed the gene encoding the $\mathrm{N}$-terminal FAST-tagged Adc fusion protein produced only traces of acetone $(0.1 \mathrm{mM})$ and exhibited 1.5-fold higher fluorescence compared to the autofluorescence of the empty vector control strain (Fig. $6 \mathrm{~b}$ and Table 4). The control strain E. limosum [pMTL83251_P $\mathrm{P}_{\text {thlA_act }}$ ], expressing the non-FAST-tagged native genes of the APO controlled by the $\mathrm{P}_{\text {thlA }}$ promoter, reached an $\mathrm{OD}_{600}$ of 3 , had a growth rate of $0.15 \mathrm{~h}^{-1}$, and produced acetate, butyrate as well as
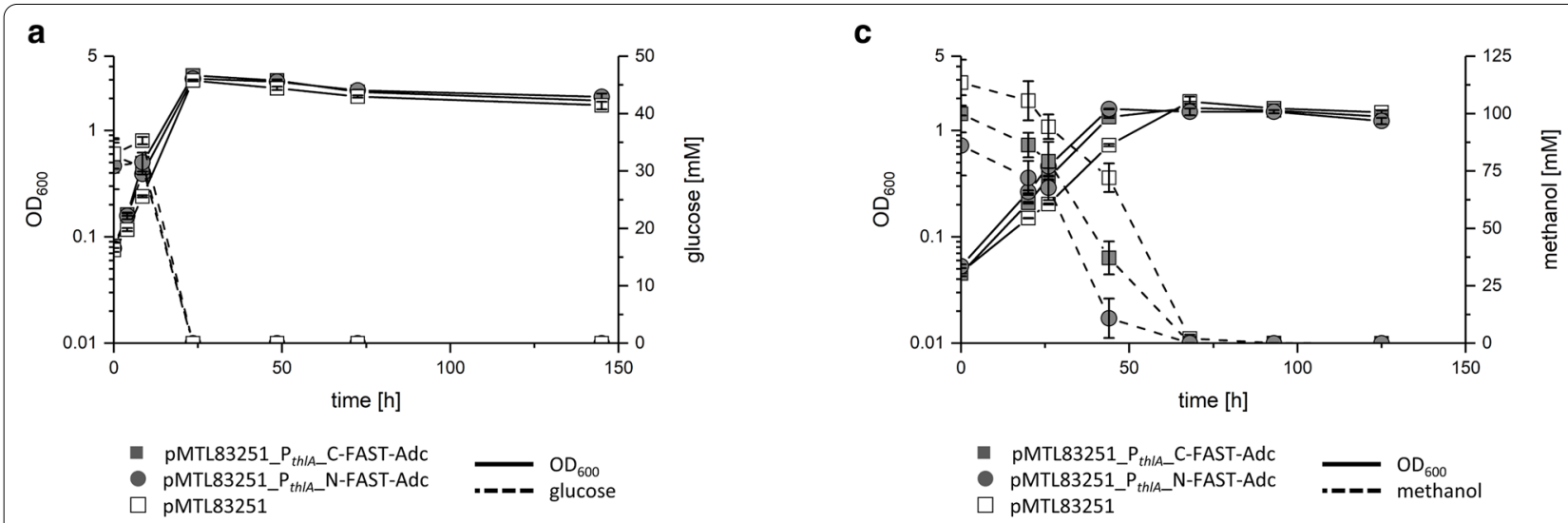

b

d
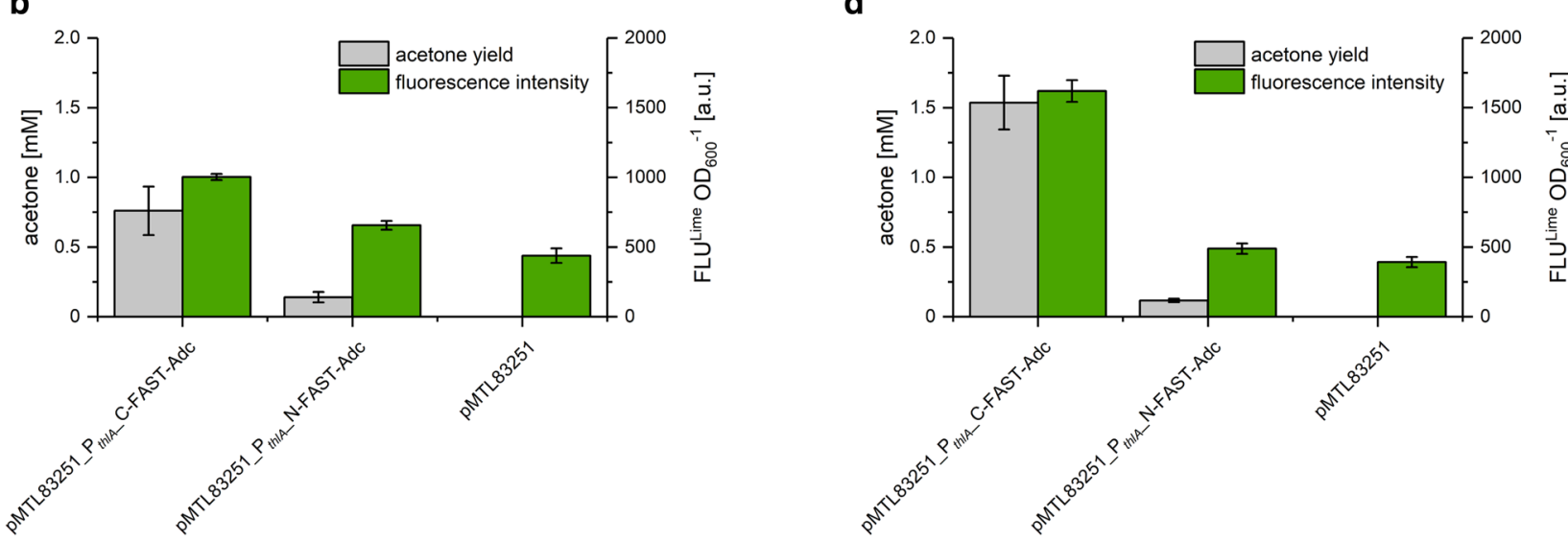

Fig. 6 Growth experiment using E. limosum [pMTL83251_P th/A_C-FAST-Adc], E. limosum [pMTL83251_P th/A_N-FAST-Adc], and E. limosum [pMTL83251]. Cells were cultivated using a, b $30 \mathrm{mM}$ glucose or $\mathbf{c}, \mathbf{d} 100 \mathrm{mM}$ methanol as carbon source. Displayed are $\mathbf{a}, \mathbf{c} \mathrm{OD}_{600}$ and substrate consumption as well as $\mathbf{b}, \mathbf{d}$ maximal acetone concentrations and fluorescence intensities. Error bars indicate standard deviations. $n=3$ 
Table 4 Growth characteristics and acetone production of recombinant E. limosum strains characterized in growth experiments using glucose or methanol as carbon source

\begin{tabular}{|c|c|c|c|c|c|c|}
\hline \multirow[t]{2}{*}{ Recombinant E. limosum strains } & \multicolumn{3}{|c|}{ Cultivated using glucose } & \multicolumn{3}{|c|}{ Cultivated using methanol } \\
\hline & $\mathrm{OD}_{\max }$ & $\begin{array}{l}\text { Growth rate } \\
\left(\mathrm{h}^{-1}\right)\end{array}$ & Acetone (mM) & $O D_{\max }$ & $\begin{array}{l}\text { Growth rate } \\
\left(\mathrm{h}^{-1}\right)\end{array}$ & Acetone (mM) \\
\hline pMTL83251_P thiA_act & 3 & 0.15 & 0.8 & 1.7 & 0.06 & 0.3 \\
\hline pMTL83251_P thlA_C-FAST-AdC & 3.3 & 0.15 & 0.8 & 1.6 & 0.08 & 1.6 \\
\hline pMTL83251_P th/A_N-FAST-AdC & 3.1 & 0.15 & 0.1 & 1.6 & 0.07 & 0.1 \\
\hline
\end{tabular}

$0.8 \mathrm{mM}$ acetone (Additional file 1: Fig. S2A and Table 4). The empty vector control E. limosum [pMTL83251] had a maximal growth rate of $0.17 \mathrm{~h}^{-1}$, reached a maximal $\mathrm{OD}_{600}$ of 2.5 , showed only autofluorescence, and did not produce any acetone.

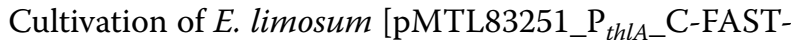
Adc] and E. limosum [pMTL83251_P $\mathrm{P}_{\text {thlA_N-FAST-Adc] }}$ using methanol as a carbon source resulted in maximal growth rates of 0.08 and $0.07 \mathrm{~h}^{-1}$, respectively (Fig. $6 \mathrm{c}$ and Table 4). Both cultures reached a maximal $\mathrm{OD}_{600}$ of 1.6 and produced acetate, butyrate, and acetone (Additional file 1: Table S2 and Table 4). E. limosum [pMTL83251_ $\mathrm{P}_{\text {thlA_C-FAST-Adc] produced the highest amount of ace- }}$ tone $(1.6 \mathrm{mM})$ cultivated using methanol, while the strain E. limosum [pMTL83251_P ${ }_{\text {thlA_N-FAST-Adc] expressing }}$ the gene encoding $\mathrm{N}$-terminal tagged Adc fusion protein only produced $0.1 \mathrm{mM}$ acetone. Fluorescence intensity of

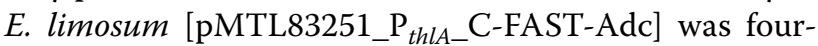
and three-fold higher compared to the fluorescence of $E$. limosum [pMTL83251] and E. limosum [pMTL83251_ $\mathrm{P}_{\text {thla_N}}$-FAST-Adc], respectively (Fig. 6d). E. limosum [pMTL83251_P thlA_C-FAST-Adc] cultivated using methanol showed a twofold higher acetone production as well as fluorescence intensity when compared to the cells cultivated using glucose. E. limosum [pMTL83251_ $\mathrm{P}_{\text {thlA_}} \mathrm{N}$-FAST-Adc] showed minor fluorescence and low amounts of acetone under both conditions tested. $E$. limosum [pMTL83251_P ${ }_{\text {thlA_act }}$ cultivated using methanol reached an $\mathrm{OD}_{600}$ of 1.7 , had a growth rate of $0.6 \mathrm{~h}^{-1}$, and produced acetate and butyrate in a ratio of $2: 1$ and $0.3 \mathrm{mM}$ acetone (Additional file 1: Fig S2B, Table 4). The empty vector control $E$. limosum [pMTL83251] reached a maximal $\mathrm{OD}_{600}$ of 1.9 with a growth rate of $0.07 \mathrm{~h}^{-1}$, did not produce any acetone, and only showed autofluorescence in the presence of ${ }^{\mathrm{TF}}$ Lime.

\section{Discussion}

\section{Methanol promotes butyrate production in E. limosum}

Since we are aiming to produce butanol and acetone using recombinant E. limosum strains, different carbon sources were investigated as alternatives to commonly used sugars. Therefore, we focused on non-food feedstock-derived $\mathrm{C} 1$ carbon sources such as methanol, $\mathrm{H}_{2}$ $+\mathrm{CO}_{2}$, and $\mathrm{CO}$ containing syngas and their impact on growth behavior and product spectrum of E. limosum. Cultivation of E. limosum using methanol resulted in higher growth rates compared to cells cultivated with the $\mathrm{C} 1$ gases as reported before $[43,44]$. The $\mathrm{C} 1$ carbon sources clearly influenced the product spectrum of E. limosum, since high amounts of methanol (200 $\mathrm{mM}$ ) resulted in improved butyrate production titers. Methanol is oxidized to $\mathrm{CO}_{2}$ via the WLP which provides three mol $\mathrm{NAD}(\mathrm{P}) \mathrm{H}$ per methyl group oxidized $[45,47]$. The $\mathrm{NAD}(\mathrm{P}) \mathrm{H}-\mathrm{NAD}(\mathrm{P})^{+}$balance is regulated during butyrate production since the reactions catalyzed by 3-hydroxybutyryl-CoA dehydrogenase and crotonase are NADH dependent and, therefore, regenerate $\mathrm{NAD}(\mathrm{P})^{+}$. Thus, the acetate:butyrate ratio shifts in favor of butyrate when cells grow on methanol [46]. Moreover, the utilization of methanol yields 1.83 ATP/ butyrate, while $\mathrm{H}_{2}+\mathrm{CO}_{2}$ utilization only yields $1 \mathrm{ATP} /$ butyrate [47]. As shown for C. autoethanogenum and A. woodii mutants, improved ATP supply benefits fast growth and abolishes acetate production [48, 49]. In general, cultivation with methanol results in high efficiencies of bioproduction compared to the cultivation with the $C 1$ gases [50,51]. High amounts of methanol (200 mM) had no clear negative impact on the growth of E. limosum. Thus, sustainably produced methanol could be a promising substitute for glucose and C1 gases as substrate. During our experiments, the wildtype strain E. limosum NG-6894 did not produce any butanol. However, E. callanderi KIST612 (former E. limosum KIST612) produces low amounts of butyrate from methanol [52] as well as traces of butanol from CO [53]. Natural butanol production from C1 gases is reported for the methanol-utilizing acetogen Butyribacterium methylotrophicum, which is closely related to E. limosum [54]. In B. methylotrophicum, the production of one mol butanol from methanol requires six reducing equivalents and yields 1.5 ATP/butanol [47]. 
Establishment of FAST as fluorescent reporter in E. limosum We established FAST as a fluorescent reporter protein for E. limosum and determined the fluorescence of $f e g$ expressing cells using a microplate reader, fluorescence microscopy, and flow cytometry. Lactoseinduced expression of $f e g$ caused bright fluorescence of respective E. limosum cells, no matter if fluorescence analytics were carried out under aerobic or anaerobic conditions. Interestingly, the bgaR- $\mathrm{P}_{b g a L}$ lactose-inducible system originating from $C$. perfringens was tightly regulated in $E$. limosum, since only cells with induced feg expression showed bright fluorescent cells. This tightly regulated expression of the $b g a R-\mathrm{P}_{b g a L}$ promoter was also reported for C. perfringens [55] C. acetobutylicum [56], and C. ljungdahlii [17], while gene expression was found to be leaky in $A$. woodii [49]. Moreover, we also showed constitutive FAST production with the $\mathrm{P}_{\text {thlA }}$ promoter from $C$. acetobutylicum. This constitutive expression caused improved fluorescence of cells compared to the lactose-induced feg expression. As of yet, only a very limited number of fluorescent proteins were shown to be somewhat functional in anaerobes, since the fluorescence of the most common fluorescent reporters including GFP and its derivatives is oxygen dependent [57]. Mostly, the flavin mononucleotidebased fluorescent proteins (FbFPs) [58] were used in anaerobes as fluorescent reporters as reported for Clostridium cellulolyticum [26], Clostridioides difficile, Clostridium acetobutylicum, Clostridium sordellii [35], C. ljungdahlii [59], Clostridium beijerinckii [60], and Clostridium tyrobutyricum [61]. Moreover, Shin et al. [13] established an engineered FbFP version (CreiLOV) as a reporter gene in E. limosum ATCC8486. Although FbFPs are functional under anoxic conditions, they show a fairly low brightness compared to control strains that do not express the respective fluorescent protein. In contrast, the FAST system was recently established in C. acetobutylicum and C. ljungdahlii and showed a clear and obvious fluorescence [31, 32, 62]. The fluorescence of recombinant $E$. limosum strains expressing feg constructed in this work is up to 26-fold improved compared to the control strain. Thus, FAST seems to be perfectly suited as a fluorescent reporter for anaerobic bacteria. An alternative to FAST could be the SNAPand the Halo-Tag, which were shown to be functional in C. acetobutylicum and C. ljungdahlii [32]. Both tags show oxygen-independent bright fluorescence when covalently bound to a fluorogenic ligand. However, both tags require a quite long labeling time. Moreover, compared to the $14 \mathrm{kDa}$ of FAST the SNAP- and HaloTag are larger proteins with a mass of 19.4 and $33 \mathrm{kDa}$ respectively. In sum, FAST seems to be best suited for the construction of fusion proteins.
As dimerized fluorescent proteins can result in brighter fluorescence [63], we used tdFAST2 to improve fluorescence brightness with $E$. limosum. Compared to cells producing FAST, Tebo et al. [64] could show a 3.8-fold brighter fluorescence of tdFAST2-producing HEK 293 $\mathrm{T}$ cells. Here, we achieved a 1.5 -fold improved fluorescence by expressing the codon-optimized gene encoding tdFAST2 in E. limosum confirming the findings of Tebo et al. [64] that production of tdFAST2 improves fluorescence brightness. With approx. $28 \mathrm{kDa}$, the molecular mass of tdFAST2 is comparable to the mass of EGFP or mCherry [65]. The improved brightness of tdFAST2 also improves the detection limit of tdFAST2-tagged proteins which might be important especially for protein localization experiments [66]. As we only showed a 1.5-fold improved fluorescence of tdFAST2, we chose the less bright but smaller FAST for the construction of AdhE2 and Adc fusion proteins.

Fluorescence microscopy of FAST-producing E. limosum cells revealed that plasmid-based induced expression of feg caused bright fluorescent E. limosum cells showing an inhomogeneous population. This finding was confirmed by respective flow cytometry experiments which revealed that the number of fluorescent cells varies between 72 and 59\%. Such a phenotypic heterogeneity of bacterial populations with plasmid-based induced gene expression was previously reported [67-69]. One possible reason that might cause these heterogeneous populations is the usage of the lactose-inducible promoter system. The resulting $f e g$ gene expression may not only depend on the amount of inducer, but also on the uptake mechanism of the inducer molecule [68]. The lactose-inducible bgaR- $\mathrm{P}_{\text {bgaL }}$ system was also used in $C$. perfringens to express the gene $y f p$-pilB which encodes a yellow fluorescent protein-tagged fusion protein and caused an inhomogeneous fluorescent population [55]. In this experiment, Hartman et al. [55] reported that YFP-PilB was detected in $73 \%$ of the cells. Moreover, the inhomogeneous population might be caused by plasmid instability or even the loss of the plasmid encoding the reporter gene [67]. Siebert et al. [69] reported an inhomogeneous population of Oligotropha carboxidovorans which expressed the gene encoding mCherry in a plasmid-based manner. The reported inhomogeneity was overcome by the genomic integration of the respective gene encoding mCherry into the genome of Oligotropha carboxidovorans. Genomic integration of feg into E. limosum should be possible using the CRISPR-Cas9 genome editing tool [13].

Five different fluorogens are commercially available at The Twinkle Factory which can bind FAST and its variants to form the fluorescent FAST:fluorogen complex $[33,70]$. Expression of $f e g$ or the gene encoding tdFAST2 
resulted in green or red fluorescence when ${ }^{\mathrm{TF}}$ Lime or ${ }^{\mathrm{TF}}$ Coral was used, respectively. As different bacteria and proteins show autofluorescence upon excitation with different wavelength [34, 71, 72], FAST should be considered as a fluorescent reporter protein in a large variety of bacteria as the choice of the fluorogen can be adapted to the spectral conditions needed for the study. Recently, Tebo et al. [73] reported two engineered FAST versions termed greenFAST and redFAST. While greenFAST binds ${ }^{\mathrm{TF}}$ Lime, redFAST only binds ${ }^{\mathrm{TF}}$ Coral, which we showed can both be used in E. limosum. These two FAST variants augmented the FAST system and facilitate applications including two-color or even mixed culture imaging in anoxic environments.

\section{C- and N-terminally tagged AdhE2 and Adc fusion protein construction}

In this study, we designed AdhE2 and Adc FAST-tagged fusion proteins and expressed respective genes in recombinant E. limosum strains. The X-ray crystal structure of Adc (3BH2) originating from C. acetobutylicum was provided by Ho et al. [74], but to our knowledge there is none for AdhE2 from C. acetobutylicum. Based on the crystal structure, first hints can be derived if either the $\mathrm{C}$ - or N-terminal end of the protein should be tagged without causing negative impacts regarding the folding, activity, and productivity of the enzyme. The probability of creating a functional fusion protein was maximized as both the $\mathrm{C}$ - and $\mathrm{N}$ - terminal tagged versions of both Adc and AdhE2 were constructed [75]. This approach diminishes the risk of constructing non-functional fusion proteins since the interactions of the $\mathrm{C}$ - and $\mathrm{N}$ - terminal end with other structures within the enzyme are unpredictable, especially for AdhE2. We further used a flexible GS linker as it was shown to promote proper folding of the enzyme and improves the stability of fusion proteins [76]. We cloned the native genes and genes encoding the FAST-tagged fusion proteins without affecting non-coding regions including promoters. As a result, the native genes as well as the genes encoding the FAST-tagged fusion proteins were expressed under the control of the same promoter. We consequently assume that native and tagged genes are transcribed at comparable levels.

The increasing fluorescence of $E$. limosum [pMTL83251_P ${ }_{\text {bgaL_C-FAST-AdhE2] and E. limosum }}$

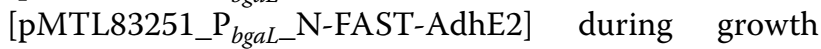
proves the production of the $\mathrm{C}$ - and $\mathrm{N}$-terminal tagged AdhE2 fusion proteins after induction of gene expression. Butanol production with strains producing the $\mathrm{C}$ - and $\mathrm{N}$-terminal tagged AdhE2 fusion proteins prove that AdhE2 is still functional even with the fluorescent tag. The functionality of the $\mathrm{N}$-terminal tagged version of AdhE2 seems not to be affected since the respective strain produced similar amounts of alcohols as the strain expressing the non-tagged native adhE2 of C. acetobutylicum. However, the productivity of the C-terminal tagged version seems slightly reduced since less alcohol was produced compared to the strains just expressing adhE2. In addition to butanol, ethanol was produced, since AdhE2 converts not only butyryl-CoA to butanol but also acetylCoA to ethanol via the respective aldehyde [77]. Interestingly, if cells of both strains were cultivated with glucose as carbon source, fluorescence of the $\mathrm{N}$ - and C-terminal tagged fusion proteins was improved compared to cultivation on methanol. This also indicates an improved production of the fusion proteins. Moreover, both strains cultivated on glucose produced more butanol as well as ethanol compared to the cells of the respective strain cultivated using methanol. This finding indicates a coherence between the fluorescence of cells expressing genes encoding adhE2 fusion proteins and the amount of recombinantly produced product.

In the case of the constitutive production of FASTtagged Adc fusion proteins, only the C-terminal FAST-tagged version of Adc produced by E. limosum [pMTL83251_P $\mathrm{P}_{\text {thla_C-FAST-Adc] showed clear fluo- }}$ rescence. The strain E. limosum [pMTL83251_P thlA_NFAST-Adc] producing the $\mathrm{N}$-terminal tagged version of Adc only showed a low fluorescence intensity and acetone productivity. Several factors might affect the fluorescence brightness of fluorescent fusion proteins including intrinsic brightness, folding efficiency, and translation efficiency [78]. Adc itself forms a homododecameric complex with a total mass of $365 \mathrm{kDa}$ [74]. We assume, based on the X-ray structure, that the free C-terminal end of the non-tagged Adc subunits is not interfering with any residues of the protein and, therefore, not harming folding efficiency. However, the $\mathrm{N}$-terminal end of Adc seems to form hydrogen bonds with LYS45, ARG44, VAL47, and GLU49 of the closest subunit. Therefore, the fusion of FAST with the sterically hindered $\mathrm{N}$-terminal end might indeed affect the folding efficiency of the fusion protein or even prevents the formation of the homododecameric complex [79]. In contrast, the folding efficiency of the C-terminal FAST-tagged Adc does not seem to be affected as cells producing the respective fusion protein are fluorescent. Heterologous expression of $a d c$ originating from C. acetobutylicum and the FAST-tagged variants with E. limosum might result in inefficient translation regarding their different codon usage [80]. Adapting $a d c$ as well as genes encoding respective FAST-tagged Adc fusion proteins to the codon usage of E. limosum might improve translation efficiency causing enhanced protein production and improved fluorescence brightness. Nevertheless, E.

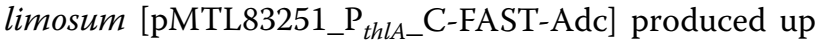


to $0.8 \mathrm{mM}$ acetone when cultivated with glucose and 1.6 $\mathrm{mM}$ from methanol providing evidence that the C-terminal tagged Adc fusion protein is functional and forms the catalytically active homododecameric Adc complex. E. limosum [pMTL83251_P ${ }_{\text {thlA_act }}$ expressing the native genes of the APO produced $0.8 \mathrm{mM}$ and $0.3 \mathrm{mM}$ acetone when cultivated with glucose or methanol, respectively. This finding shows that the productivity of the C-terminal tagged Adc fusion protein is not negatively affected. To our knowledge, acetone was neither produced with E. limosum nor from the sustainable $\mathrm{C} 1$ carbon source methanol before. Although acetone production from methanol seems to be promising, several improvements of this recombinant pathway must be performed including codon harmonization, genomic integration, and bioreactor experiments which usually show a beneficial effect on bioproduction.

\section{Conclusions}

In this study, we implemented the fluorescent activating and absorption shifting tag as an oxygen-independent fluorescent reporter protein in E. limosum. We showed that this reporter protein is functional under various growth conditions and can be adapted to the natural spectral properties of the organism using different fluorogens. We showed that the fluorescence of feg-expressing cells can be determined using a microplate reader, fluorescence microscopy, or flow cytometry. Butanol, as well as acetone, was produced by expressing the native genes of $C$. acetobutylicum and genes encoding fluorescent FAST-tagged fusion proteins. The expression of the genes encoding the fluorescent FAST-tagged fusion proteins enabled to monitor protein production during growth. We showed that those fusion proteins are functional and that the productivity is not negatively affected, however, dependent on which end the protein was tagged. The use of FAST as a fluorescence reporter not only expands the molecular toolbox of E. limosum but also is a promising reporter tool for other anaerobic bacteria as well. For the first time, we could show the production of the biocommodities acetone and butanol from methanol with recombinant E. limosum strains.

\section{Methods}

Strains, medium, and cultivation

The strains used in this study are listed in Table 5. E. coli DH5 $\alpha$ was used for plasmid cloning and cultivated in liquid modified lysogeny broth (1\% tryptone, $1 \% \mathrm{NaCl}$, $0.5 \%$ yeast extract) [81] while shaking or on respective agar plates at $37{ }^{\circ} \mathrm{C}$. When required medium was supplemented with $250 \mu \mathrm{g} \mathrm{mL}{ }^{-1}$ erythromycin. E. limosum NG-6894 was cultivated in modified DSM 135 medium under strictly anaerobic conditions at $37^{\circ} \mathrm{C}$. The modified DSM 135 medium contained $12.9 \mathrm{mM} \mathrm{KH_{2 }} \mathrm{PO}_{4}$, $48.5 \mathrm{mM} \mathrm{K}_{2} \mathrm{HPO}_{4}, 18.7 \mathrm{mM} \mathrm{NH}_{4} \mathrm{Cl}, 49.6 \mathrm{mM} \mathrm{NaCl}, 58.9$ $\mathrm{mM} \mathrm{KHCO}, 2.8 \mathrm{mM}$ L-cysteine- $\mathrm{HCl}, 1.5 \mathrm{mM} \mathrm{MgSO}_{4}$, $4.4 \mu \mathrm{M}$ resazurin, $0.2 \%$ (wt/vol) yeast extract, $0.1 \%$ (vol/ vol) trace element solution SL-9 [82], 0.1\% (vol/vol) selenite-tungstate solution [82], and $0.2 \%$ ( $\mathrm{vol} / \mathrm{vol}$ ) vitamin solution DSM 141. If necessary, the medium was sup-

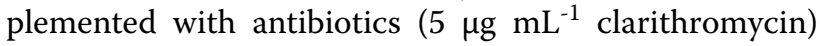
after autoclaving. Heterotrophic cultivations of E. limosum was carried out in $50 \mathrm{~mL}$ medium in $125 \mathrm{~mL}$ Müller-Krempel flasks and were supplemented with $30 \mathrm{mM}$ glucose or 50,100 or $200 \mathrm{mM}$ methanol. Autotrophic cultivations were also carried out in $50 \mathrm{~mL}$ medium in $500 \mathrm{~mL}$ Müller-Krempel flasks, which were pressurized to 1.1 bar overpressure with $\mathrm{H}_{2}+\mathrm{CO}_{2}\left(67 \% \mathrm{H}_{2}+33 \%\right.$ $\left.\mathrm{CO}_{2}\right)$ or syngas $\left(10 \% \mathrm{CO}_{2}, 40 \% \mathrm{CO}, 10 \% \mathrm{~N}_{2}, 40 \% \mathrm{H}_{2}\right)$ and repressured when below 0.5 bar. Before growth experiments were carried out, cells were grown from DMSO stock cultures in $5 \mathrm{~mL}$ of the respective medium. These $5 \mathrm{~mL}$ cultures were used to prepare $50 \mathrm{~mL}$ precultures supplemented with glucose or methanol for subsequent growth experiments. For autotrophic growth experiments, cells from $5 \mathrm{~mL}$ cultures were adapted to growth conditions by transferring them two times to fresh $50 \mathrm{~mL}$ medium in $500 \mathrm{~mL}$ Müller-Krempel culture flasks with the respective gas atmosphere.

\section{Plasmid construction}

All plasmids and primers used in this study are listed in Tables 6 and 7, respectively. DNA fragments for cloning purposes were amplified using the KAPA Hifi

Table 5 Strains used in this study

\begin{tabular}{|c|c|c|}
\hline Strain & Description & Source \\
\hline E. coli DH5a & E. coli for plasmid construction & $\begin{array}{l}\text { Thermo Fisher } \\
\text { Scientific Inc., } \\
\text { Waltham, MA, } \\
\text { USA }\end{array}$ \\
\hline E. limosum NG-6894 & $\begin{array}{l}\text { This strain grows on a defined medium (without any yeast extract) and does not } \\
\text { produce any sticky polymers }\end{array}$ & $\begin{array}{l}\text { Prof. Philippe } \\
\text { Soucaille, INSA, } \\
\text { University of Tou- } \\
\text { louse, France }\end{array}$ \\
\hline
\end{tabular}


polymerase (Kapa Biosystem, Sigma-Aldrich Chemie $\mathrm{GmbH}$, Munich, Germany). Primers used in this study were synthesized by biomers.net GmbH (Ulm, Germany) and designed to have a 15-25 nucleotide overlap with the respective vector DNA. Vector DNA for cloning purposes was linearized using Fast digest enzymes (Thermo Fisher Scientific Inc., Waltham, USA). PCR and digested vector DNA fragments were purified using the NucleoSpin ${ }^{\circledR}$ Gel and PCR clean-up kit (Macherey-Nagel GmbH \& Co. KG, Düren, Germany). All plasmids were constructed by assembling PCR and vector DNA fragments using the NEBuilder Hifi DNA Assembly Cloning Kit according to the manufacturer's protocol (New England Biolabs, Ipswich, MA, USA). Assembled plasmids were used for the transformation of chemically competent $E$. coli $\mathrm{DH} 5 \alpha$ cells and verified via Sanger sequencing (Eurofins Genomics GmbH, Luxemburg).

To establish FAST as a reporter protein in E. limosum, plasmids harboring $f e g$ were constructed. Therefore, $f e g$ was amplified together with the promoter $\mathrm{P}_{t h l}$ sup from

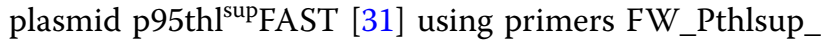
FAST_NdeI and RV_Pthlsup_FAST_XhoI (Table 7). The amplified PCR fragment was cloned via NdeI and XhoI recognition sites into vector pMTL83251 resulting in the plasmid pMTL83251_P thl $_{\text {sup }}$ FAST. The promoter region of $\mathrm{P}_{\text {thl }}$ sup from plasmid pMTL83251_ $\mathrm{P}_{\text {thl }}^{\text {sup_FAST was }}$ further exchanged with the lactose-inducible bgaR-P $\mathrm{P}_{b g a L}$ system from C. perfringens [55] and $\mathrm{P}_{\text {thla }}$ from C. acetobutylicum [18]. Therefore, the bgaR-PbgaL-encoding DNA fragment was amplified from plasmid pMTL83151 gusA_P bgaL [49] using the primers FW_PbgaL_NdeI and RV_PbgaL_BamHI. The DNA fragment containing the promoter region of $\mathrm{P}_{\text {thla }}$ was amplified from plasmid pJIR750_act [18] using primers FW_Pthl_NdeI and RV_Pthl_BamHI (Table 7). Both promoter containing DNA fragments were assembled with pMTL83251 $\mathrm{P}_{t h l}^{\text {sup }}$ FAST (excision of $\mathrm{P}_{t h l}^{\text {sup }}$ ) resulting in plasmids pMTL83251_P ${ }_{\text {thla_}}$ FAST and pMTL83251_P ${ }_{b g a L}$ FAST.

The gene $f e g$ of pMTL83251_P $\mathrm{P}_{b g a L}$ FAST was exchanged with the gene encoding tdFAST2. The sequence of tdFAST2 was obtained from Tebo et al. [64] and codon optimized for E. limosum using the GENEius tool (Eurofins Genomics GmbH, Luxemburg) and synthesized by Eurofins Genomics Germany GmbH (Ebersberg, Germany). The gene tdFAST2-opt was amplified from the delivered plasmid pEX-A128_tdFAST2-opt using the primers FW_tdFAST2-opt_BamHI and RV_tdFAST2opt_XhoI (Table 7) and ligated with BamHI and XhoI digested pMTL83251_P ${ }_{b g a L}$ FAST (excision of $f e g$ ) vector DNA resulting in plasmid pMTL83251_P $\mathrm{P}_{\text {bgaL }}$ tdFAST2.

For butanol production with E. limosum, the plasmid pMTL83251_P $\mathrm{P}_{\text {bgaL_AdhE2 }}$ was constructed. The gene adhE2 was amplified from genomic DNA of $C$. acetobutylicum using primers $\mathrm{FW}$ _C1_adhe 2 and $\mathrm{RV}$ N2_adhE2 (Table 7). The gene was assembled under the control of the lactose-inducible bgaR-P ${ }_{\text {bgal }}$ promoter using the plasmid DNA of pMTL83251_P ${ }_{\text {bgaL_}}$ FAST, which was digested using BamHI and XhoI (excision of feg).

For acetone production with E. limosum, the plasmid pMTL83251_P thlA_act $_{\text {a }}$ was constructed encoding the genes of the APO under the control of promoter $\mathrm{P}_{\text {thlA }}$. The origin of these genes as well as their locus tags are listed in Table 6. These genes as well as the DNA fragment containing the promoter region of $\mathrm{P}_{\text {thlA }}$ were amplified from plasmids pJIR750_act using primers FW_act_NdeI and RV_act_XhoI (Table 7). The amplified PCR fragments were cloned via the NdeI and XhoI restriction sites of pMTL83251 resulting in the plasmids pMTL83251_P thlA_act.

Moreover, plasmids were constructed to produce Cand $\mathrm{N}$ - terminal FAST-tagged fusion proteins of AdhE2 and Adc. FAST was $\mathrm{C}$ - and $\mathrm{N}$-terminal fused to AdhE2 or Adc using a glycine linker (GGGGS) with the sequence ggtggtggtggttct. For the construction of C-terminal tagged fusion proteins, the 3 ' end of the gene of interest was fused to the 5' end of $f e g$. Therefore, the gene of interest was amplified without its stop codon while $f e g$ was amplified without its start codon. To construct N-terminal FAST-tagged fusion proteins, the $3^{\prime}$ end of $f e g$ was fused to the $5^{\prime}$ end of the gene of interest. The gene of interest was amplified without its start codon, while feg was amplified without its stop codon.

The plasmid pMTL83251_P constructed to produce the C-terminal FAST-tagged AdhE2 fusion protein. adhE2 was amplified from plasmid pMTL83251_P and RV_C1_adhE2-FAST (Table 7), feg was amplified from plasmid pMTL83251_P ${ }_{b g a L}$ FAST using primers FW_C2_adhE2-FAST and RV_C2_FAST (Table 7). Primers RV_C1_adhE2-FAST and FW_C2_adhE2FAST contain the sequence for the glycine-linker. The plasmid pMTL83251_P ${ }_{b g a L}$ N-FAST-AdhE2 was constructed to produce the N-terminal FAST-tagged AdhE2 fusion protein. adhE2 was amplified from plasmid pMTL83251_P ${ }_{\text {bgaL_AdhE2 }}$ using primers FW_N1_adhE2 and RV_N1_FAST-adhE2 while feg was amplified from plasmid pMTL83251_P $\mathrm{P}_{\text {bgaL }}$ FAST using primers $\mathrm{FW}_{-}$ N2_FAST-adhE2 and RV_N2_adhE2 (Table 7). Primers RV_N1_FAST-adhE2 and FW_N2_FAST-adhE2 contain the sequence for the glycine linker.

The plasmid pMTL83251_P ${ }_{\text {thlA_C-FAST-Adc }}$ was constructed to produce the C-terminal FAST-tagged Adc fusion protein. $a d c$ was amplified from plasmid pMTL83251_P $\mathrm{P}_{\text {thla_act }}$ using primers $\mathrm{FW}$ _C1_adc and RV_C1_adc-FAST, and $f e g$ was amplified from plasmid 
Table 6 Plasmids used in this study

\begin{tabular}{|c|c|c|}
\hline Plasmid & Description & Source \\
\hline pMTL83251 & ColE1 ori', pCB102 ori $^{+}$, Emr', traJ, lacZ & [83] \\
\hline pMTL83151_gusA_P bgal & ColE1 ori, pCB102 ori $^{+}, \mathrm{Cm}^{r}$, traJ, lacZ, gusA from E. coli, bgaR-P $\mathrm{P}_{\text {bal }}$ from C. perfringens & [49] \\
\hline pJIR750_act & $\begin{array}{l}\text { pJIR750; } P_{\text {thll }} \text { thIA (CAC2873), ctfA/B (CA_P0163/P0164), adc (CA_P0165) from C. } \\
\text { acetobutylicum }\end{array}$ & [18] \\
\hline p95thl $1^{\text {sup FAST }}$ & ColE1 ori', repL ori ${ }^{+}, \mathrm{Amp}^{r}, \mathrm{Em} \mathrm{m}^{r}, \mathrm{lacZ}, \mathrm{P}_{\text {thl }}$ sup , feg & [31] \\
\hline pMTL83251_P thl Sup $_{\text {FAST }}$ & pMTL83251; $P_{\text {thl }}^{\text {sup }}$, feg from p95thl ${ }^{\text {sup FAST }}$ & This work \\
\hline pMTL83251_P th/A_FAST & PMTL83251; $P_{\text {th/A, }}$ from pMTL83251_P $P_{\text {th/A_act; }}$ feg from p95thl sup FAST & This work \\
\hline pMTL83251_P bgal_FAST & 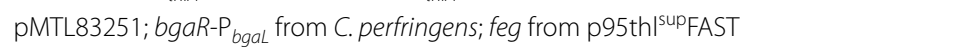 & This work \\
\hline pEX-A128_tdFAST2-opt & pUC ori', Ampr', MSC, gene encoding tdFAST2 codon optimized for E. limosum & $\begin{array}{l}\text { Eurofins Genomics Germany } \\
\text { GmbH, Ebersberg, Ger- } \\
\text { many }\end{array}$ \\
\hline pMTL83251_P bgal_tdFAST2 & $\begin{array}{l}\text { pMTL83251; bgaR-P } \text { bgal }_{\text {from C. perfringens; gene encoding tdFAST2 codon optimized }} \\
\text { for E. limosum }\end{array}$ & This work \\
\hline pMTL83251_P bgal_AdhE2 & pMTL83251; bgaR-P bgaL from C. perfringens; adhE2 from C. acetobutylicum & This work \\
\hline pMTL83251_P bgal_C-FAST-AdhE2 & 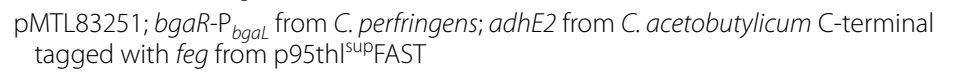 & This work \\
\hline pMTL83251_P bgal_N-FAST-AdhE2 & 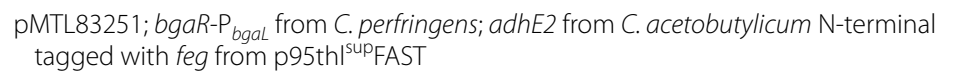 & This work \\
\hline pMTL83251_P thiA_act & pMTL83251; $\mathrm{P}_{\text {thl' }}$ thIA, ctfA/B, adc from pJIR_act & This work \\
\hline pMTL83251_P thiA_C-FAST-AdC & $\begin{array}{l}\text { pMTL83251; } P_{\text {thlA, }} \text { thIA, ctfA/B, from pJIR_act; adc from C. acetobutylicum C-terminal } \\
\text { tagged with feg from p95thl IupFAST }\end{array}$ & This work \\
\hline pMTL83251_P thiA_N-FAST-Adc & $\begin{array}{l}\text { pMTL83251; } P_{\text {thliA }} \text {, thlA, ctfA/B, from pJIR_act; adc from C. acetobutylicum N-terminal } \\
\text { tagged with feg from p95thl }{ }^{\text {sup }} \text { FAST }\end{array}$ & This work \\
\hline
\end{tabular}

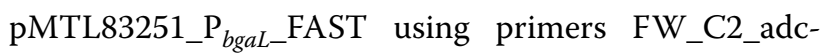
FAST and RV_C2_FAST (Table 7). Primers RV_C1_adcFAST and FW_C2_adc-FAST contain the sequence for the glycine linker. The plasmid pMTL83251_P ${ }_{t h l A \_} \mathrm{N}$ FAST-Adc was constructed to produce the N-terminal FAST-tagged Adc fusion protein. The gene adc was amplified from plasmid pMTL83251_P primers FW_N1_adc-FAST and RV_N1_FAST-adc and feg was amplified from plasmid pMTL83251_P ${ }_{b g a L}$ FAST using primers FW_N2_FAST-adc and RV_N2_adc (Table 7). Primers RV_N1_FAST-adc and FW_N2_FASTadc contain the sequence for the glycine linker.

\section{Transformation}

Electroporation and preparation of electrocompetent E. limosum cells were performed according to the protocol of Leang et al. [84] with several modifications. All steps were carried out under anaerobic conditions in an anaerobic chamber (gas atmosphere 95\% $\mathrm{N}_{2}$ and 5\% $\mathrm{H}_{2}$ ). Plastic materials were placed $24 \mathrm{~h}$ before use into the anaerobic chamber to remove any traces of oxygen. For the preparation of electrocompetent cells, E. limosum was cultivated at $37{ }^{\circ} \mathrm{C}$ in $100 \mathrm{~mL}$ modified DSM 135 medium supplemented with $100 \mathrm{mM}$ methanol and $40 \mathrm{mM}$ DL-Threonine. Cells were cultivated until the early exponential growth phase $\left(\mathrm{OD}_{600} 0.3-0.5\right)$ and harvested by centrifugation at $7690 \times g$ for $10 \mathrm{~min}$ at $4{ }^{\circ} \mathrm{C}$.
Subsequently, cells were washed two times with anaerobic SMP buffer (270 mM sucrose, $1 \mathrm{mM} \mathrm{MgCl}_{2}, 7 \mathrm{mM}$ $\mathrm{NaH}_{2} \mathrm{PO}_{4}, \mathrm{pH}$ 6) by centrifugation at $7.690 \times g$ for $10 \mathrm{~min}$ at $4{ }^{\circ} \mathrm{C}$. Afterwards, the cell pellet was suspended in 648 $\mu \mathrm{L}$ SMP buffer and $72 \mu \mathrm{L}$ DMSO, distributed into cryotubes, and stored at $-80^{\circ} \mathrm{C}$ until use.

Transformation of E. limosum cells was performed using 3-5 $\mu \mathrm{g}$ plasmid DNA, which were added to 25 $\mu \mathrm{L}$ of electrocompetent cells into a pre-cooled $1 \mathrm{~mm}$ electroporation cuvette (Biozym Scientific $\mathrm{GmbH}$, Oldendorf, Germany). Cells were pulsed (625 V, 25 $\mu \mathrm{F}, 600 \Omega$; Gene Pulser Xcell ${ }^{\mathrm{TM}}$, Bio-Rad Laboratories $\mathrm{GmbH}$, Munich, Germany) and immediately transferred into $5 \mathrm{~mL}$ fresh medium. E. limosum cells were recovered at $37{ }^{\circ} \mathrm{C}$ in $5 \mathrm{~mL}$ modified DSM 135 medium supplemented with $100 \mathrm{mM}$ methanol. The $\mathrm{OD}_{600}$ of transformed cells was monitored. After one or two doublings, $5 \mu \mathrm{g} \mathrm{mL}{ }^{-1}$ clarithromycin was added to the medium for selection of recombinant strains. After a further increase of the $\mathrm{OD}_{600}$, which indicates a successful transformation, cells were transferred two more times into fresh medium supplemented with 5 $\mu \mathrm{g} \mathrm{mL} \mathrm{m}^{-1}$ of clarithromycin. Successfully transformed cells were verified by isolation of plasmid DNA using the Zyppy ${ }^{\mathrm{TM}}$ Plasmid Miniprep Kit (Zymo Research, Irvine, CA, USA). This preparation was used to transform chemically competent $E$. coli $\mathrm{DH} 5 \alpha$ cells 
Table 7 Primers used in this study

\begin{tabular}{|c|c|c|}
\hline Primer & Sequence $5^{\prime}-3^{\prime}$ & Length (bp) \\
\hline FW_C1_adhE2 & ttaaatgtattgggagggtggatccatgaaagttacaaatcaaaaagaac & 50 \\
\hline RV_N2_adhE2 & agcttgcatgtctgcaggcctcgagttaaaatgattttatatagatatccttaagttc & 58 \\
\hline FW_act_Ndel & gaccgcggccgctgtatccatatgtcaagaagaggcac & 38 \\
\hline RV_act_Xhol & agcttgcatgtctgcaggcctcgagttacttaagataatcatatataacttcag & 54 \\
\hline FW_Pthlsup_FAST_Ndel & atgaccgcggccgctgtatccatatgtttttaacaaaaagtattgaaatttg & 52 \\
\hline RV_Pthlsup_FAST_Xhol & aagcttgcatgtctgcaggectcgagtcataccctcttaac & 41 \\
\hline FW_PbgaL_Ndel & gaccgcggccgctgtatccatatgtaatttagatattaattctaaattaagtgaaattaatatag & 65 \\
\hline RV_PbgaL_BamHI & caaatgctacgtgttccatggatccaccctcccaatacatttaaaataattatg & 54 \\
\hline FW_Pthl_Ndel & gaccgcggccgctgtatccatatgtcaagaagaggcacctcatc & 44 \\
\hline RV_Pthl_BamHI & caaatgctacgtgttccatggatcctaacctcctaaattttgatacgg & 48 \\
\hline FW_tdFAST2-opt_BamHI & ttaaatgtattgggagggtggatccatggagcatgtagcttttg & 44 \\
\hline RV_tdFAST2-opt_Xhol & agcttgcatgtctgcaggectcgagtcaaacccgtttgacgaag & 44 \\
\hline RV_C1_adhE2-FAST & ctacgtgttcagaaccaccaccaccaaatgattttatatagatatccttaagttc & 55 \\
\hline FW_C2_adhE2-FAST & aaaatcatttggtggtggtggttctgaacacgtagcatttggaag & 45 \\
\hline RV_C2_FAST & agcttgcatgtctgcaggectcgagtcataccctcttaacgaaaac & 46 \\
\hline FW_N1_FAST & ttaaatgtattgggagggtggatccatggaacacgtagcatttg & 44 \\
\hline RV_N1_FAST-adhE2 & ttgtaactttagaaccaccaccacctaccctcttaacgaaaac & 43 \\
\hline FW_N2_FAST-adhE2 & taagagggtaggtggtggtggttctaaagttacaaatcaaaaagaactaaaac & 53 \\
\hline FW_C1_adc & acccatggetgtttaggtaccttttatgttaaaggatgaagtaattaaac & 50 \\
\hline RV_C1_adc-FAST & ctacgtgttcagaaccaccaccacccttaagataatcatatataacttcagc & 52 \\
\hline FW_C2_adc-FAST & ttatcttaagggtggtggtggttctgaacacgtagcatttggaag & 45 \\
\hline FW_N1_FAST-adc & acccatggctgtttaggtaccttttatggaacacgtagcatttg & 44 \\
\hline RV_N1_FAST-adc & catcctttaaagaaccaccaccacctaccctcttaacgaaaac & 43 \\
\hline FW_N2_FAST-adc & taagagggtaggtggtggtggttctttaaaggatgaagtaattaaacaaattag & 54 \\
\hline RV_N2_adc & agcttgcatgtctgcaggcctcgagttacttaagataatcatatataacttcag & 54 \\
\hline
\end{tabular}

to amplify the plasmids. After transformation, plasmids were isolated and checked by restriction analysis. Recombinant strains were stored in cryotubes with $10 \%$ DMSO at $-80{ }^{\circ} \mathrm{C}$. All recombinant strains constructed in this study are listed in Table 8.

\section{Fluorescence determination}

Fluorescence of FAST and FAST-tagged fusion proteinproducing recombinant E. limosum strains, cultivated anaerobically until the stationary growth phase, were determined using a microplate reader, fluorescence microscopy, or flow cytometry. Therefore, $2 \mathrm{~mL}$ culture broth was taken anaerobically during growth and

Table 8 Recombinant strains used in this study

\begin{tabular}{|c|c|c|}
\hline Recombinant strain & Plasmid & Reference \\
\hline E. limosum [pMTL83251] & pMTL83251 & This work \\
\hline E. limosum [pMTL83251_P $\mathrm{P}_{\text {th/A_ }}$ FAST] & pMTL83251_P thlA_ $_{\text {FAST }}$ & This work \\
\hline E. limosum [pMTL83251_P bgal_FAST] & pMTL83251_P bgaL_FAST & This work \\
\hline E. limosum [pMTL83251_P bgaL_tdFAST2] & pMTL83251_P bgal_tdFAST2 & This work \\
\hline E. limosum [pMTL83251_P bgaL_AdhE2] & pMTL83251_P bgal_AdhE2 & This work \\
\hline E. limosum [pMTL83251_P bgal_C-FAST-AdhE2] & pMTL83251_P bgal_C-FAST-AdhE2 & This work \\
\hline E. limosum [pMTL83251_P bgaL_N-FAST-AdhE2] & pMTL83251_P bgal_N-FAST-AdhE2 & This work \\
\hline E. limosum [pMTL83251_P th/A_act] & pMTL83251_P th/A_act & This work \\
\hline E. limosum [pMTL83251_P thlA_C-FAST-Adc] & pMTL83251_P thiA_C-FAST-AdC $_{1}$ & This work \\
\hline E. limosum [pMTL83251_P thlA_N-FAST-Adc] & pMTL83251_P thiA_N-FAST-Adc & This work \\
\hline
\end{tabular}


harvested by centrifugation at $7711 \times g$ for 15 minutes at $4^{\circ} \mathrm{C}$. The supernatant was discarded and harvested cells were washed with anaerobic PBS buffer $(137 \mathrm{mM} \mathrm{NaCl}$, $2.7 \mathrm{mM} \mathrm{KCl}, 10 \mathrm{mM} \mathrm{Na} 2 \mathrm{HPO}_{4}, 1.8 \mathrm{mM} \mathrm{KH}_{2} \mathrm{PO}_{4}$ ) followed by centrifugation at $7711 \times g$ for 15 minutes at $4{ }^{\circ} \mathrm{C}$. Cell pellets were suspended in anaerobic PBS buffer (end $\left.\mathrm{OD}_{600} 1\right)$.

\section{Microplate reader}

$100 \mu \mathrm{L}$ of suspended cells was transferred to black flatbottomed 96-well microtiter plates (Greiner Bio-One $\mathrm{GmbH}$, Frickenhausen, Deutschland) and supplemented with $10 \mu \mathrm{M}$ fluorogen of the green dye ${ }^{\mathrm{TF}} \mathrm{Lime}$ (ex. 480/ em. 541) or the red dye ${ }^{\mathrm{TF}}$ Coral (ex. 516/em. 600) (The Twinkle Factory, France, Paris). Excitation and emission wavelengths both correspond to the respective maximum of the fluorogen. Fluorescence intensities of the whole population were determined using the SYNERGY H1 microplate reader (BioTek, Bad Friedrichshall, Germany) located in an anaerobic chamber and finally normalized to the $\mathrm{OD}_{600}$ of PBS-washed cells.

\section{Fluorescence microscopy}

Washed cells were stained with $10 \mu \mathrm{M}{ }^{\mathrm{TF}}$ Lime and transferred onto an 1\% agarose pad on a microscopy slide, covered with a glass coverslip, and sealed with nail polish. Cells were viewed with a $63 x$ objective, using a Zeiss Axio Observer Z1 (Zeiss, Oberkochen, Germany). Green fluorescence of the FAST:fluorogen complex was detected using the Zeiss filter set $38 \mathrm{HE}$ (ex. BP 470/40, em. BP $525 / 50$ ). Data were analyzed using the Zeiss Zen 2.6 blue edition software.

\section{Flow cytometry}

Washed cells were stained with $10 \mu \mathrm{M}{ }^{\mathrm{TF}}$ Lime diluted in PBS buffer (end $\mathrm{OD}_{600}: 0.01$ ). Green fluorescence of the FAST:fluorogen complex was assessed using an excitation wavelength of $488 \mathrm{~nm}$ and a 528/46 nm emission filter. For analysis, at least 10,000 events were recorded using an Amnis ${ }^{\circledR}$ CellStream ${ }^{\circledR}$ flow cytometer (Luminex Corporation, Austin, TX, USA). Acquired data were analyzed using the CellStreamTM Analysis tool version 1.2.152 (Luminex Corporation, Austin, TX, USA).

\section{Analytics}

$2 \mathrm{~mL}$ samples were withdrawn from cell cultures during the growth of $E$. limosum to analyze $\mathrm{OD}_{600}$, product spectrum as well as substrate consumption. After $\mathrm{OD}_{600}$ of the withdrawn culture broth was determined at 600 $\mathrm{nm}$ using the GENESYS 10vis photometer (Thermo Scientific, Waltham, MA, USA), the remaining culture was centrifuged at $17,968 \times g$ for 20 minutes at $4{ }^{\circ} \mathrm{C}$ to remove cell debris. The supernatant was used for HPLC and GC analysis.

\section{High-performance liquid chromatography}

The concentration of glucose, acetate, and butyrate from culture supernatant was determined using the Agilent 1260 Infinity II HPLC system (Agilent Technologies, Santa Clara, CA, USA), equipped with a diode array detector and a refractive index detector. To achieve separation, $20 \mu \mathrm{L}$ of the supernatant was injected into the organic acid resin $150 \times 8 \mathrm{~mm}$ column (CS-chromatographie-Service $\mathrm{GmbH}$, Langerwehe, Germany) packed with polystyrene divinylbenzene copolymer operating at a constant temperature of $40{ }^{\circ} \mathrm{C}$. As mobile phase, $5 \mathrm{mM}$ $\mathrm{H}_{2} \mathrm{SO}_{4}$ was used with a flow rate of $0.7 \mathrm{~mL} \mathrm{~min}^{-1}$. The software OpenLAB CDS ChemStation Edition A.01.03 (Agilent Technologies, Santa Clara, CA, USA) was used for data analysis.

\section{Gas chromatography}

The concentration of methanol, ethanol, butanol, and acetone in the culture broth was analyzed via gas chromatography. A PerkinElmer Clarus 680 GC system (Perkin Elmer LAS GmbH, Waltham, MA, USA) equipped with an Elite-FFAP capillary column (length $30 \mathrm{~m} x$ inner diameter $0.32 \mathrm{~mm}$, film thickness $0.25 \mu \mathrm{m}$ ) (Perkin Elmer LAS GmbH, Waltham, MA, USA) and FID detector was used. Supernatants were acidified with $2 \mathrm{M} \mathrm{HCL}$. $\mathrm{H}_{2}$ was used as the carrier gas. The injector and detector were operated at 225 and $300{ }^{\circ} \mathrm{C}$, respectively. $0.5 \mu \mathrm{L}$ of the culture broth was injected into the gas chromatograph and analyzed using the following temperature profile: 40 ${ }^{\circ} \mathrm{C}$ for 2.5 minutes; $40{ }^{\circ} \mathrm{C}-250{ }^{\circ} \mathrm{C}$ with $40{ }^{\circ} \mathrm{C} \mathrm{min}-1 ; 250{ }^{\circ} \mathrm{C}$ for 2 minutes.

\section{Abbreviations}

Adc: Acetoacetate decarboxylase; AdhE2: Bifunctional acetaldehyde/alcohol dehydrogenase; APO: Acetone production operon; FAST: Fluorescence-activating and absorption shifting tag; $\mathrm{OD}_{600}$ : Optical density; $\mathrm{POI}$ : Protein of interest.

\section{Supplementary Information}

The online version contains supplementary material available at https://doi. org/10.1186/s13068-021-01966-2.

Additional file 1. Fig. S1. Growth experiment with E. limosum [pMTL83251_P bgal_AdhE2] and E. limosum [pMTL83251]. Strains were cultivated using $30 \mathrm{mM}$ glucose (A) or $100 \mathrm{mM}$ methanol (B) as carbon source. Gene expression of cells was either induced by lactose or noninduced. Induction with lactose is indicated with the vertical dotted line. Monitored are $\mathrm{OD}_{600}$, methanol consumption, as well as acetate, butyrate, ethanol, and butanol production. Error bars indicate standard deviations. $\mathrm{n}=3$. Fig. S2. Growth experiment with E. limosum [pMTL83251_P th/A_act] and E. limosum [pMTL83251]. Strains were cultivated using $30 \mathrm{mM}$ glucose (A) or $100 \mathrm{mM}$ methanol (B) as carbon source. Monitored are $\mathrm{OD}_{600}$, glucose and methanol consumption, as well as acetate, butyrate, 
and acetone production. Error bars indicate standard deviations. $n=3$. Table S1. Growth characteristics and product formation of recombinant E. limosum strains characterized in growth experiments using glucose as carbon source. Table S2. Growth characteristics and product formation of recombinant E. limosum strains characterized in growth experiments using methanol as carbon source.

\section{Acknowledgements}

We thank Eleftherios (Terry) Papoutsakis (Delaware Biotechnology Institute, University of Delaware, Newark, DE, USA) for kindly providing the plasmid

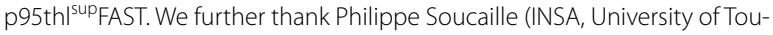
louse, Toulouse, France) for providing the strain E. limosum NG-6894.

\section{Authors' contributions}

$M F, F R B$, and $P D$ designed the experiments. MF and GL performed the experiments. MF analyzed the data and wrote the manuscript. FRB and PD participated in writing the manuscript and revised the paper. All authors read and approved the final manuscript.

\section{Funding}

Open Access funding enabled and organized by Projekt DEAL. This research was funded by the European Research Area Cofund on BioTechnologies (ERACoBioTech) within the 1st Joint Call (project BIOMETCHEM, grant 161B0609A).

\section{Availability of data and materials}

All data generated during this study are included in this article and the additional files. Raw data are available on reasonable request.

\section{Declarations}

Ethics approval and consent to participate Not applicable.

\section{Consent for publication}

Not applicable.

\section{Competing interests}

The authors declare that they have no competing interests.

Received: 27 January 2021 Accepted: 29 April 2021

Published online: 10 May 2021

\section{References}

1. Acharya B, Roy P, Dutta A. Review of syngas fermentation processes for bioethanol. Biofuels. 2014;5:551-64. https://doi.org/10.1080/17597269. 2014.1002996.

2. Bertau M, Offermanns H, Plass L, Schmidt F, Wernicke HJ. Methanol: the basic chemical and energy feedstock of the future. Heidelberg: Springer; 2014

3. Sheldon D. Methanol production - a technical history. Johns Matthey Technol Rev. 2017;61:172-82. https://doi.org/10.1595/205651317X 695622.

4. Bengelsdorf FR, Beck MH, Erz C, Hoffmeister S, Karl MM, Riegler P, et al. Bacterial anaerobic synthesis gas (syngas) and $\mathrm{CO}_{2}+\mathrm{H}_{2}$ fermentation. In: Advances in Applied Microbiology. Elsevier; 2018. p. 143-221. https://doi. org/https://doi.org/10.1016/bs.aambs.2018.01.002.

5. Pfeifenschneider J, Brautaset T, Wendisch VF. Methanol as carbon substrate in the bio-economy: metabolic engineering of aerobic methylotrophic bacteria for production of value-added chemicals. Biofuel Bioprod Bior. 2017;11:719-31. https://doi.org/10.1002/bbb.1773.

6. Schrader J, Schilling M, Holtmann D, Sell D, Filho MV, Marx A, et al. Methanol-based industrial biotechnology: current status and future perspectives of methylotrophic bacteria. Trends Biotechnol. 2009;27:107-15. https://doi.org/10.1016/j.tibtech.2008.10.009.
7. Weijma J, Stams AJM. Methanol conversion in high-rate anaerobic reactors. Water Sci Technol. 2001;44:7-14. https://doi.org/10.2166/wst.2001. 0452.

8. Bache R, Pfennig N. Selective isolation of Acetobacterium woodii on methoxylated aromatic acids and determination of growth yields. Arch Microbiol. 1981;130:255-61. https://doi.org/10.1007/BF00459530.

9. Kremp F, Poehlein A, Daniel R, Müller V. Methanol metabolism in the acetogenic bacterium Acetobacterium woodii. Environ Microbiol. 2018;20:4369-84. https://doi.org/10.1111/1462-2920.14356.

10. Mueller AP, Köpke M. Recombinant microorganisms and uses therefor. Washington, DC; US 2013/03300809 A1, 2013.

11. Huang H, Chai C, Li N, Rowe P, Minton NP, Yang S, et al. CRISPR/Cas9based efficient genome editing in Clostridium ljungdahlii, an autotrophic gas-fermenting bacterium. ACS Synth Biol. 2016;5:1355-61. https://doi. org/10.1021/acssynbio.6b00044.

12. Nagaraju S, Davies NK, Walker DJF, Köpke M, Simpson SD. Genome editing of Clostridium autoethanogenum using CRISPR/Cas9. Biotechnol Biofuels. 2016;9:15. https://doi.org/10.1186/s13068-016-0638-3.

13. Shin J, Kang S, Song Y, Jin S, Lee JS, Lee J-K, et al. Genome engineering of Eubacterium limosum using expanded genetic tools and the CRISPR-Cas9 system. ACS Synth Biol. 2019;8:2059-68. https://doi.org/10.1021/acssy nbio.9b00150.

14. Jin S, Bae J, Song Y, Pearcy N, Shin J, Kang S, et al. Synthetic biology on acetogenic bacteria for highly efficient conversion of $\mathrm{C} 1$ gases to biochemicals. Int J Mol Sci. 2020;21:7639. https://doi.org/10.3390/ijms2 1207639.

15. Köpke M, Held C, Hujer S, Liesegang H, Wiezer A, Wollherr A, et al. Clostridium ljungdahlii represents a microbial production platform based on syngas. Proc Natl Acad Sci USA. 2010;107:13087-92. https://doi.org/10. 1073/pnas.1004716107.

16. Köpke M, Liew F. Production of butanol from carbon monoxide by a recombinant microorganism. Washington, DC; US 2011/0236941, 2011.

17. Banerjee A, Leang C, Ueki T, Nevin KP, Lovley DR. Lactose-inducible system for metabolic engineering of Clostridium ljungdahlii. Appl Environ Microbiol. 2014;80:2410-6. https://doi.org/10.1128/AEM.03666-13.

18. Hoffmeister S, Gerdom M, Bengelsdorf FR, Linder S, Flüchter S, Öztürk H, et al. Acetone production with metabolically engineered strains of Acetobacterium woodii. Metab Eng. 2016;36:37-47. https://doi.org/10.1016/j. ymben.2016.03.001

19. Jones SW, Fast AG, Carlson ED, Wiedel CA, Au J, Antoniewicz MR, et al. $\mathrm{CO}_{2}$ fixation by anaerobic non-photosynthetic mixotrophy for improved carbon conversion. Nat Commun. 2016;7:12800. https://doi.org/10.1038/ ncomms12800.

20. Bengelsdorf FR, Poehlein A, Linder S, Erz C, Hummel T, Hoffmeister S, et al. Industrial acetogenic biocatalysts: a comparative metabolic and genomic analysis. Front Microbiol. 2016;7:5. https://doi.org/10.3389/fmicb.2016. 01036.

21. Woolston BM, Emerson DF, Currie DH, Stephanopoulos G. Rediverting carbon flux in Clostridium ljungdahlii using CRISPR interference (CRISPRi). Metab Eng. 2018;48:243-53. https://doi.org/10.1016/j.ymben.2018.06. 006.

22. Flüchter S, Follonier S, Schiel-Bengelsdorf B, Bengelsdorf FR, Zinn M, Dürre P. Anaerobic production of poly(3-hydroxybutyrate) and its precursor 3-hydroxybutyrate from synthesis gas by autotrophic clostridia. Biomacromolecules. 2019;20:3271-82. https://doi.org/10.1021/acs.biomac. 9 b00342.

23. Chalfie M, Tu Y, Euskirchen G, Ward W, Prasher D. Green fluorescent protein as a marker for gene expression. Science. 1994;263:802-5. https://doi. org/10.1126/science.8303295.

24. Landete JM, Medina M, Arqués JL. Fluorescent reporter systems for tracking probiotic lactic acid bacteria and bifidobacteria. World J Microbiol Biotechnol. 2016;32:119. https://doi.org/10.1007/s11274-016-2077-5.

25. Changsen C, Franzblau SG, Palittapongarnpim P. Improved green fluorescent protein reporter gene-based microplate screening for antituberculosis compounds by utilizing an acetamidase promoter. Antimicrob Agents Chemother. 2003;47:3682-7. https://doi.org/10.1128/AAC.47.12 3682-3687.2003.

26. Teng L, Wang K, Xu J, Xu C. Flavin mononucleotide (FMN)-based fluorescent protein (FbFP) as reporter for promoter screening in Clostridium cellulolyticum. J Microbiol Methods. 2015;119:37-43. https://doi.org/10. 1016/j.mimet.2015.09.018. 
27. Bloemberg GV, O’Toole GA, Lugtenberg BJJ, Kolter R. Green fluorescent protein as a marker for Pseudomonas spp. Appl Environ Microbiol. 1997:63:4543-51. https://doi.org/10.1128/AEM.63.11.4543-4551.1997.

28. Southward CM, Surette MG. The dynamic microbe: green fluorescent protein brings bacteria to light: monitoring microbial dynamics with GFP. Mol Microbiol. 2002;45:1191-6. https://doi.org/10.1046/j.1365-2958.2002. 03089.x.

29. Charubin K, Bennett RK, Fast AG, Papoutsakis ET. Engineering Clostridium organisms as microbial cell-factories: challenges \& opportunities. Metab Eng. 2018;50:173-91. https://doi.org/10.1016/j.ymben.2018.07.012.

30. Plamont M-A, Billon-Denis E, Maurin S, Gauron C, Pimenta FM, Specht CG, et al. Small fluorescence-activating and absorption-shifting tag for tunable protein imaging in vivo. Proc Natl Acad Sci USA. 2016;113:497-502. https://doi.org/10.1073/pnas.1513094113.

31. Streett HE, Kalis KM, Papoutsakis ET. A strongly fluorescing anaerobic reporter and protein-tagging system for Clostridium organisms based on the fluorescence-activating and absorption-shifting tag protein (FAST). Appl Environ Microbiol. 2019;85:e00622-19. https://doi.org/10.1128/AEM. 00622-19.

32. Charubin K, Streett H, Papoutsakis ET. Development of strong anaerobic fluorescent reporters for Clostridium acetobutylicum and Clostridium ljungdahlii using HaloTag and SNAP-tag proteins. Appl Environ Microbiol. 2020;86:e01271-20. https://doi.org/10.1128/AEM.01271-20.

33. Li C, Plamont M-A, Sladitschek HL, Rodrigues V, Aujard I, Neveu P, et al. Dynamic multicolor protein labeling in living cells. Chem Sci. 2017;8:5598-605. https://doi.org/10.1039/C7SC01364G.

34. Ransom EM, Ellermeier CD, Weiss DS. Use of mCherry red fluorescent protein for studies of protein localization and gene expression in Clostridium difficile. Appl Environ Microbiol. 2015;81:1652-60. https://doi.org/10. 1128/AEM.03446-14.

35. Buckley AM, Jukes C, Candlish D, Irvine JJ, Spencer J, Fagan RP, et al. Lighting up Clostridium difficile: reporting gene expression using fluorescent Lov domains. Sci Rep. 2016:6:23463. https://doi.org/10.1038/srep23463.

36. Stockmar I, Feddersen H, Cramer K, Gruber S, Jung K, Bramkamp M, et al. Optimization of sample preparation and green color imaging using the $\mathrm{mNeonGreen} \mathrm{fluorescent} \mathrm{protein} \mathrm{in} \mathrm{bacterial} \mathrm{cells} \mathrm{for} \mathrm{photoactivated}$ localization microscopy. Sci Rep. 2018;8:10137. https://doi.org/10.1038/ s41598-018-28472-0.

37. Sharak Genthner BR, Davis CL, Bryant MP. Features of rumen and sewage sludge strains of Eubacterium limosum, a methanol- and $\mathrm{H}_{2}-\mathrm{CO}_{2}$-utilizing species. Appl Environ Microbiol. 1981;42:12-9. https://doi.org/10.1128/ AEM.42.1.12-19.1981.

38. Kang S, Song Y, Jin S, Shin J, Bae J, Kim DR, et al. Adaptive laboratory evolution of Eubacterium limosum ATCC 8486 on carbon monoxide. Front Microbiol. 2020;11:402. https://doi.org/10.3389/fmicb.2020.00402.

39. Fontaine L, Meynial-Salles I, Girbal L, Yang X, Croux C, Soucaille P. Molecular characterization and transcriptional analysis of adhE2, the gene encoding the $\mathrm{NADH}$-dependent aldehyde/alcohol dehydrogenase responsible for butanol production in alcohologenic cultures of Clostridium acetobutylicum ATCC 824. J Bacteriol. 2002;184:821-30. https://doi. org/10.1128/JB.184.3.821-830.2002.

40. Lindley ND, Loubiere P, Pacaud S, Mariotto C, Goma G. Novel products of the acidogenic fermentation of methanol during growth of Eubacterium limosum in the presence of high concentrations of organic acids. Microbiology. 1987;133:3557-63. https://doi.org/10.1099/00221287-133-12-3557.

41. Wiesenborn DP, Rudolph FB, Papoutsakis ET. Thiolase from Clostridium acetobutylicum ATCC 824 and its role in the synthesis of acids and solvents. Appl Environ Microbiol. 1988;54:2717-22. https://doi.org/10.1128/ AEM.54.11.2717-2722.1988.

42. Cornillot E, Nair RV, Papoutsakis ET, Soucaille P. The genes for butanol and acetone formation in Clostridium acetobutylicum ATCC 824 reside on a large plasmid whose loss leads to degeneration of the strain. J Bacteriol. 1997;179:5442-7. https://doi.org/10.1128/jb.179.17.5442-5447.1997.

43. Sharak Genthner BR, Bryant MP. Additional characteristics of one-carboncompound utilization by Eubacterium limosum and Acetobacterium woodii. Appl Environ Microbiol. 1987;53:471-6. https://doi.org/10.1128/ AEM.53.3.471-476.1987

44. Loubiere P, Gros E, Paquet V, Lindley ND. Kinetics and physiological implications of the growth behaviour of Eubacterium limosum on glucose/ methanol mixtures. J Gen Microbiol. 1992;138:979-85. https://doi.org/10. 1099/00221287-138-5-979.
45. Pacaud S, Loubiere P, Goma G, Lindley ND. Effects of various organic acid supplements on growth rates of Eubacterium limosum B2 on methanol. Appl Microbiol Biotechnol. 1986;24:7. https://doi.org/10.1007/BF002 66289.

46. Pacaud S, Loubiere P, Goma G. Methanol metabolism by Eubacterium limosum B2: effects of $\mathrm{pH}$ and carbon dioxide on growth and organic acid production. Curr Microbiol. 1985;12:245-50. https://doi.org/10.1007/ BF01567972.

47. Kremp F, Müller V. Methanol and methyl group conversion in acetogenic bacteria: biochemistry, physiology and application. FEMS Microbiol Rev. 2020. https://doi.org/10.1093/femsre/fuaa040.

48. Valgepea K, Loi KQ, Behrendorff JB, Lemgruber R, Plan M, Hodson MP, et al. Arginine deiminase pathway provides ATP and boosts growth of the gas-fermenting acetogen Clostridium autoethanogenum. Metab Eng. 2017;41:202-11. https://doi.org/10.1016/j.ymben.2017.04.007.

49. Beck MH, Flaiz M, Bengelsdorf FR, Dürre P. Induced heterologous expression of the arginine deiminase pathway promotes growth advantages in the strict anaerobe Acetobacterium woodii. Appl Microbiol Biotechnol. 2020;104:687-99. https://doi.org/10.1007/s00253-019-10248-9.

50. Claassens NJ, Cotton CAR, Kopljar D, Bar-Even A. Making quantitative sense of electromicrobial production. Nat Catal. 2019;2:437-47. https:// doi.org/10.1038/s41929-019-0272-0.

51. Cotton CAR, Claassens NJ, Benito-Vaquerizo S, Bar-Even A. Renewable methanol and formate as microbial feedstocks. Curr Opin Biotechnol. 2020;62:168-80. https://doi.org/10.1016/j.copbio.2019.10.002.

52. Litty D, Müller V. Butyrate production in the acetogen Eubacterium limosum is dependent on the carbon and energy source. Microb Biotechnol. 2021. https://doi.org/10.1111/1751-7915.13779.

53. Park $S$, Yasin $M$, Jeong J, Cha M, Kang H, Jang N, et al. Acetate-assisted increase of butyrate production by Eubacterium limosum KIST612 during carbon monoxide fermentation. Bioresour Technol. 2017;245:560-6. https://doi.org/10.1016/j.biortech.2017.08.132.

54. Grethlein AJ, Worden RM, Jain MK, Datta R. Evidence for production of n-butanol from carbon monoxide by Butyribacterium methylotrophicum. J Ferment Bioeng. 1991;72:58-60. https://doi.org/10.1016/0922-338X(91) 90147-9.

55. Hartman AH, Liu H, Melville SB. Construction and characterization of a lactose-Inducible promoter system for controlled gene expression in Clostridium perfringens. Appl Environ Microbiol. 2011;77:471-8. https:// doi.org/10.1128/AEM.01536-10.

56. Al-Hinai MA, Fast AG, Papoutsakis ET. Novel system for efficient isolation of Clostridium double-crossover allelic exchange mutants enabling markerless chromosomal gene deletions and DNA integration. Appl Environ Microbiol. 2012;78:8112-21. https://doi.org/10.1128/AEM.02214-12.

57. Zimmer M. Green Fluorescent Protein (GFP): applications, structure, and related photophysical behavior. Chem Rev. 2002;102:759-82. https://doi. org/10.1021/cr010142r

58. Drepper T, Eggert T, Circolone F, Heck A, Krauß U, Guterl J-K, et al. Reporter proteins for in vivo fluorescence without oxygen. Nat Biotechnol. 2007;25:443-5. https://doi.org/10.1038/nbt1293.

59. Molitor B, Kirchner K, Henrich AW, Schmitz S, Rosenbaum MA. Expanding the molecular toolkit for the homoacetogen Clostridium ljungdahlii. Sci Rep. 2016:6:31518. https://doi.org/10.1038/srep31518.

60. Seo S-O, LuT, Jin Y-S, Blaschek HP. Development of an oxygen-independent flavin mononucleotide-based fluorescent reporter system in Clostridium beijerinckii and its potential applications. J Biotechnol. 2018;265:119-26. https://doi.org/10.1016/j.jbiotec.2017.11.003.

61. Cheng C, Lin M, Jiang W, Zhao J, Li W, Yang S-T. Development of an in vivo fluorescence based gene expression reporter system for Clostridium tyrobutyricum. J Biotechnol. 2019;305:18-22. https://doi.org/10.1016/j. jbiotec.2019.08.019.

62. Charubin K, Modla S, Caplan JL, Papoutsakis ET. Interspecies microbial fusion and large-scale exchange of cytoplasmic proteins and RNA in a syntrophic Clostridium coculture. mBio. 2020;11:e02030-20. https://doi. org/10.1128/mBio.02030-20.

63. Shaner NC, Campbell RE, Steinbach PA, Giepmans BNG, Palmer AE, Tsien RY. Improved monomeric red, orange and yellow fluorescent proteins derived from Discosoma sp. red fluorescent protein. Nat Biotechnol. 2004;22:1567-72. https://doi.org/10.1038/nbt1037. 
64. Tebo AG, Pimenta FM, Zhang Y, Gautier A. Improved chemical-genetic fluorescent markers for live cell microscopy. Biochemistry. 2018;57:5648-53. https://doi.org/10.1021/acs.biochem.8b00649.

65. Day RN, Davidson MW. The fluorescent protein palette: tools for cellular imaging. Chem Soc Rev. 2009;38:2887. https://doi.org/10.1039/b901966a.

66. Tanenbaum ME, Gilbert LA, Qi LS, Weissman JS, Vale RD. A protein-tagging system for signal amplification in gene expression and fluorescence imaging. Cell. 2014;159:635-46. https://doi.org/10.1016/j.cell.2014.09.039.

67. Siegele DA, Hu JC. Gene expression from plasmids containing the araBAD promoter at subsaturating inducer concentrations represents mixed populations. Proc Natl Acad Sci USA. 1997;94:8168-72. https://doi.org/10. 1073/pnas.94.15.8168.

68. Binder D, Probst C, Grünberger A, Hilgers F, Loeschcke A, Jaeger KE, et al. Comparative single-cell analysis of different E. coli expression systems during microfluidic cultivation. PLOS ONE. 2016;11:e0160711. https://doi. org/10.1371/journal.pone.0160711.

69. Siebert D, Busche T, Metz AY, Smaili M, Queck BAW, Kalinowski J, et al. Genetic engineering of Oligotropha carboxidovorans strain OM5-a promising candidate for the aerobic utilization of synthesis gas. ACS Synth Biol. 2020;9:1426-40. https://doi.org/10.1021/acssynbio.0c00098.

70. Li C, Tebo AG, Thauvin M, Plamont M, Volovitch M, Morin X, et al. A far-red emitting fluorescent chemogenetic reporter for in vivo molecular imaging. Angew Chem Int Ed. 2020;59:17917-23. https://doi.org/10.1002/ ange.202006576.

71. Mihalcescu I, Van-Melle Gateau M, Chelli B, Pinel C, Ravanat J-L. Green autofluorescence, a double edged monitoring tool for bacterial growth and activity in micro-plates. Phys Biol. 2015;12:066016. https://doi.org/10. 1088/1478-3975/12/6/066016.

72. Surre J, Saint-Ruf C, Collin V, Orenga S, Ramjeet M, Matic I. Strong increase in the autofluorescence of cells signals struggle for survival. Sci Rep. 2018:8:12088. https://doi.org/10.1038/s41598-018-30623-2.

73. Tebo AG, Moeyaert B, Thauvin M, Carlon-Andres I, Böken D, Volovitch $M$, et al. Orthogonal fluorescent chemogenetic reporters for multicolor imaging. bioRxiv. 2020. https://doi.org/10.1038/s41589-020-0611-0.

74. Ho M-C, Ménétret J-F, Tsuruta H, Allen KN. The origin of the electrostatic perturbation in acetoacetate decarboxylase. Nature. 2009;459:393-7. https://doi.org/10.1038/nature07938.
75. Snapp E. Design and use of fluorescent fusion proteins in cell biology. Curr Protoc Cell Biol. 2005;27:1-13. https://doi.org/10.1002/0471143030. cb2104s27.

76. Chen $X$, Zaro JL, Shen W-C. Fusion protein linkers: property, design and functionality. Adv Drug Deliv Rev. 2013;65:1357-69. https://doi.org/10. 1016/j.addr.2012.09.039

77. Yoo M, Croux C, Meynial-Salles I, Soucaille P. Elucidation of the roles of adhE1 and adhE2 in the primary metabolism of Clostridium acetobutylicum by combining in-frame gene deletion and a quantitative systemscale approach. Biotechnol Biofuels. 2016;9:92. https://doi.org/10.1186/ s13068-016-0507-0.

78. Sheff MA, Thorn KS. Optimized cassettes for fluorescent protein tagging in Saccharomyces cerevisiae. Yeast. 2004;21:661-70. https://doi.org/10. 1002/yea. 1130.

79. Specht EA, Braselmann E, Palmer AE. A critical and comparative review of fluorescent tools for live-cell Imaging. Annu Rev Physiol. 2017;79:93-117. https://doi.org/10.1146/annurev-physiol-022516-034055.

80. Nieuwkoop T, Finger-Bou M, van der Oost J, Claassens NJ. The ongoing quest to crack the genetic code for protein production. Mol Cell. 2020;80:193-209. https://doi.org/10.1016/j.molcel.2020.09.014.

81. Bertani G. Studies on lysogenesis I. The mode of phage liberation by lysogenic Escherichia coli. J Bacteriol. 1951;62:293-300. https://doi.org/10. 1128/JB.62.3.293-300.1951.

82. Tschech A, Pfennig N. Growth yield increase linked to caffeate reduction in Acetobacterium woodii. Arch Microbiol. 1984;137:163-7. https://doi.org/ 10.1007/BF00414460.

83. Heap JT, Pennington OJ, Cartman ST, Minton NP. A modular system for Clostridium shuttle plasmids. J Microbiol Methods. 2009;78:79-85. https:// doi.org/10.1016/j.mimet.2009.05.004.

84. Leang C, Ueki T, Nevin KP, Lovley DR. A genetic system for Clostridium ljungdahlii: a chassis for autotrophic production of biocommodities and a model homoacetogen. Appl Environ Microbiol. 2013;79:1102-9. https:// doi.org/10.1128/AEM.02891-12.

\section{Publisher's Note}

Springer Nature remains neutral with regard to jurisdictional claims in published maps and institutional affiliations.
Ready to submit your research? Choose BMC and benefit from:

- fast, convenient online submission

- thorough peer review by experienced researchers in your field

- rapid publication on acceptance

- support for research data, including large and complex data types

- gold Open Access which fosters wider collaboration and increased citations

- maximum visibility for your research: over 100M website views per year

At BMC, research is always in progress.

Learn more biomedcentral.com/submissions 